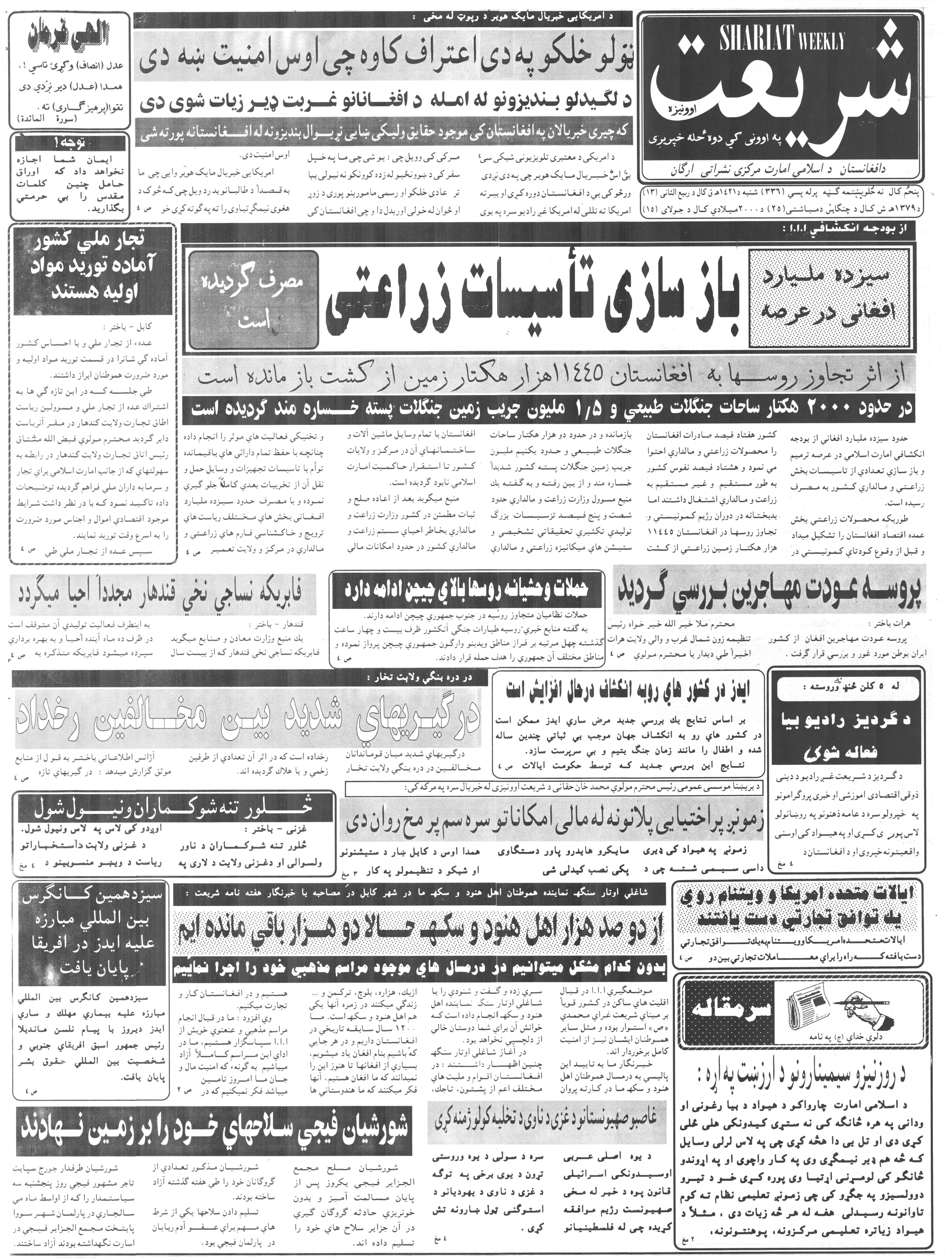




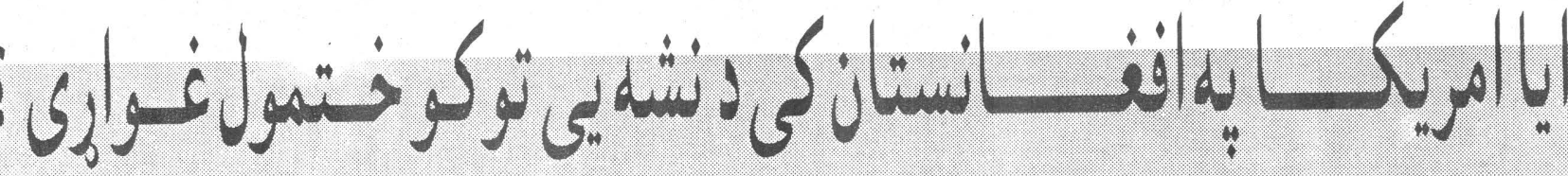

رويى مم نه لكوى 11

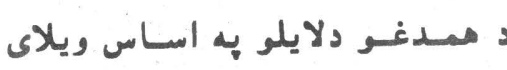

شسو جم اصلا امريكا ، ملكرى ملتونه

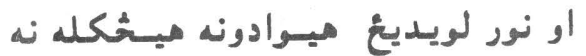

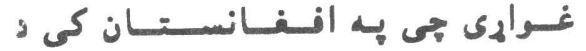

مخدراتو د منفنيوى به مكله ثمه مئبت

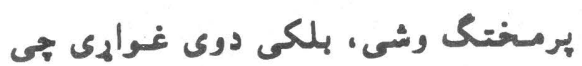

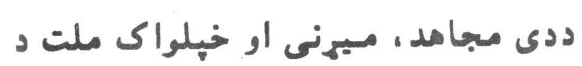

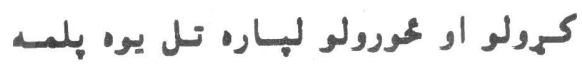

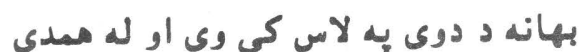

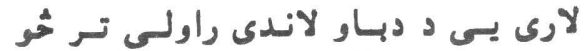

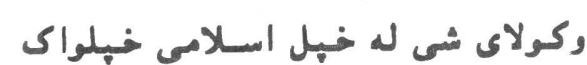

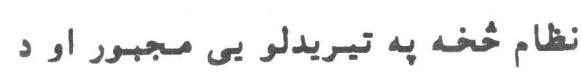

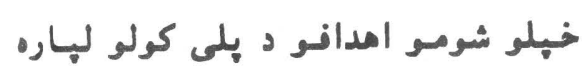
لاره هواره كرى اعري

لنده دا جمى د اتتصـادى بنديزونو

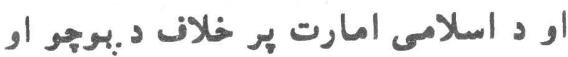

ناروا تبليفاتو ددى روان تويان مئان موخه

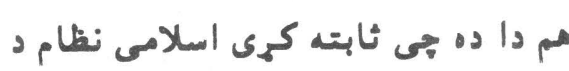

تولنى به تنظيم او سوكالى كمى نـاكام

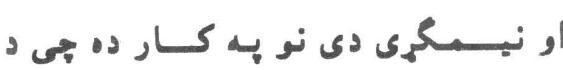

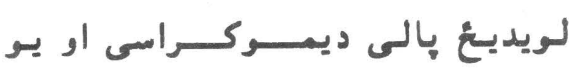

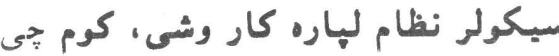

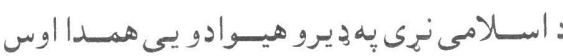

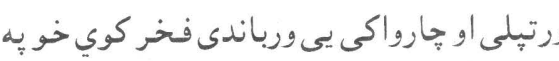

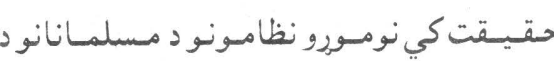

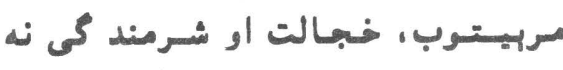

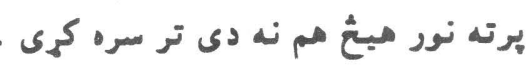

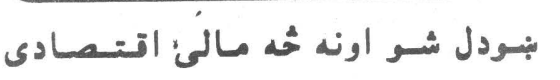

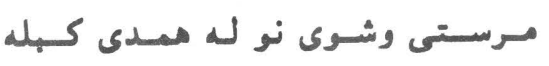
ويلاى شو جى لويديخ ميثُكله مـ نه نه

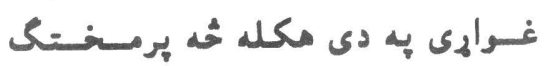
وشى او به افغنانستان كى د مستخدره موادو د كرنى مسخنيسوى وشى به دو دي

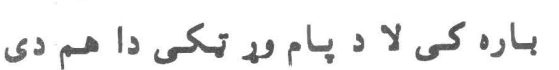

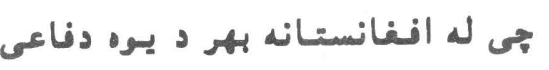

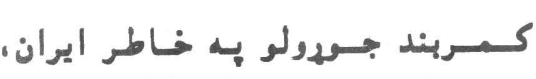
باكستان، تاجكستان او ازبكستستان

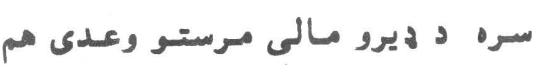
شوى او د امريكمى او ملكرو ملتور له خوا بوره دلجسـبسى ورسره بنكاره

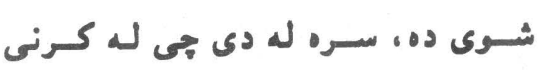
وروسته بيا د داسى اتداماتو اغيزى لهي هيرى كمى وى خو بيا مم لكيا دى او اوري

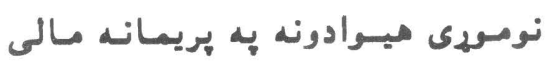

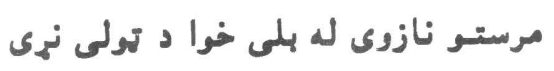

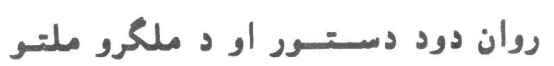

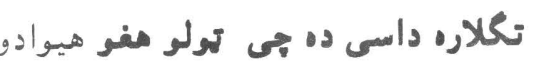

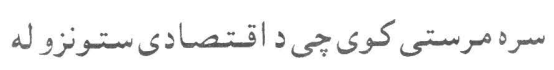
لاسه يمد مـخدراتو كرنى تهل لاس إجولى دئ

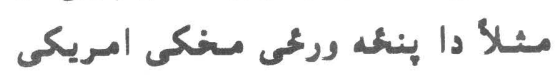
اعلان وكي جيى ن نشه بي توكو د مخنيوى ليّاره

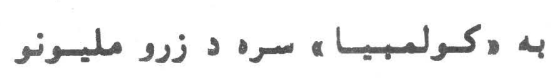

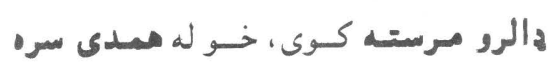

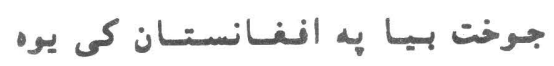

بـ بـ وخت كى زمونهي كرونده او د اوبه

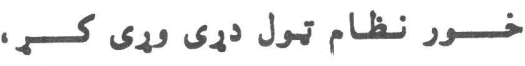

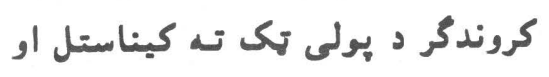

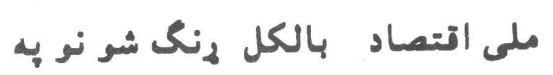

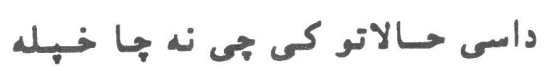

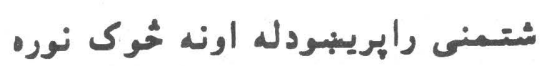

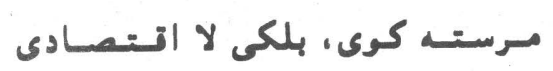

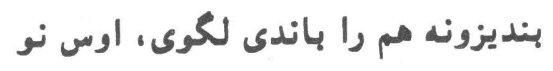
مونير دا ديرش مليونه وكرى له له لوني

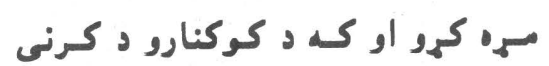
اجازه وركهو \&

مسره له دى جمى نهى وال به رهو

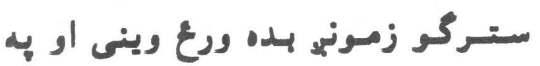

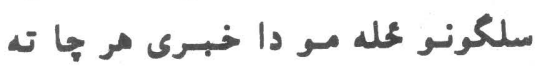

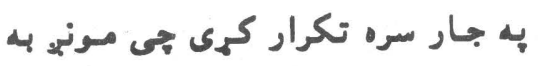

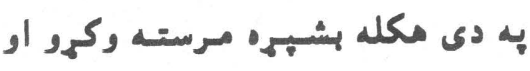

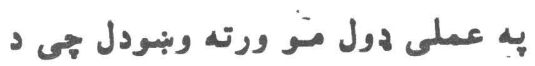

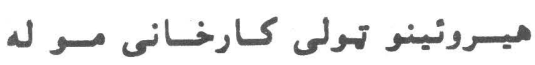

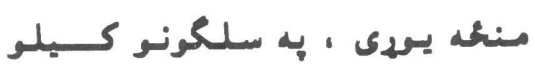

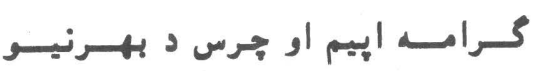

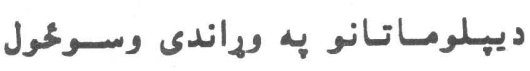

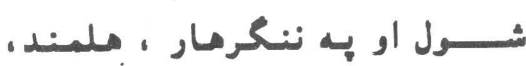

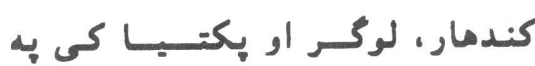

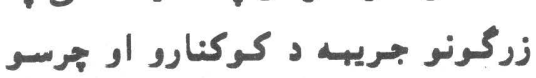

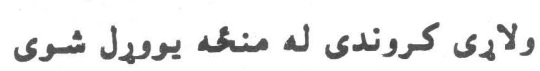

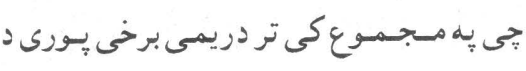

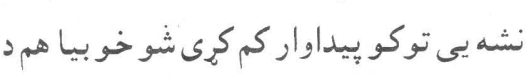

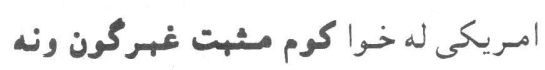

غسريه نهى د خهبلى عسمرى دورى

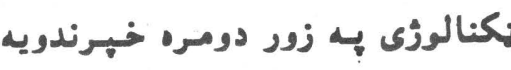
او تبليغاتى وسايل بيدا كهرى جهى بهري

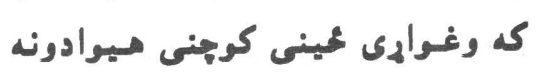

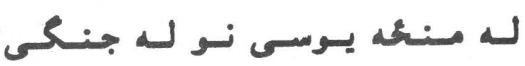

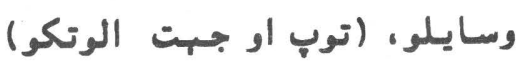

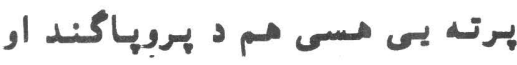

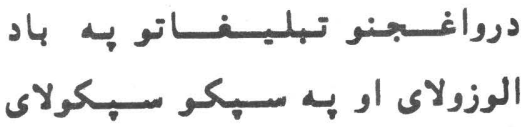

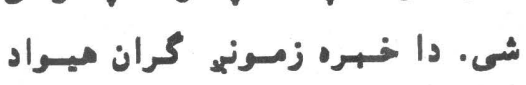

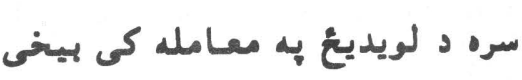

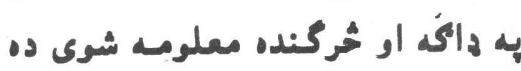

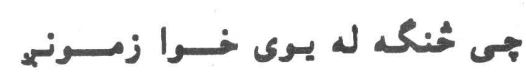

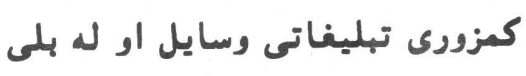

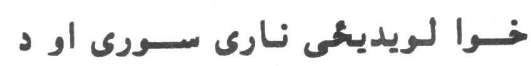

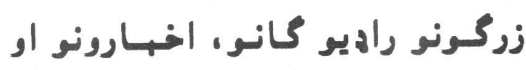

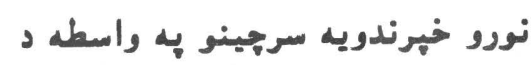
انغـانستــان اسلامى امسارت كردور

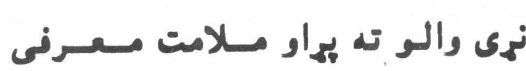

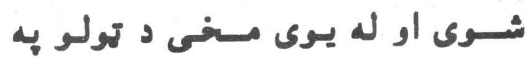

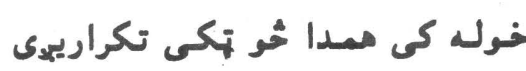

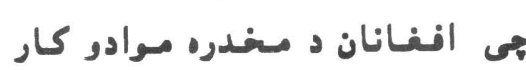

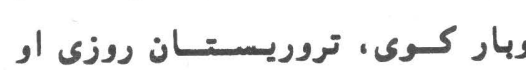

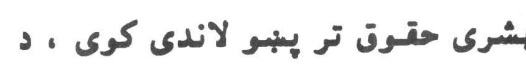

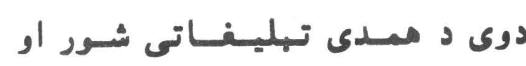

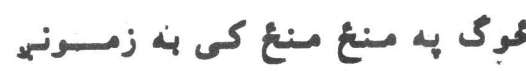

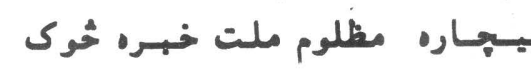

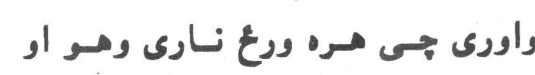

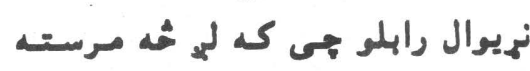

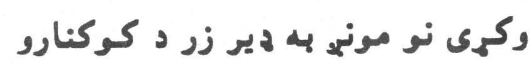

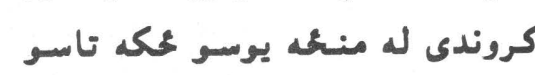

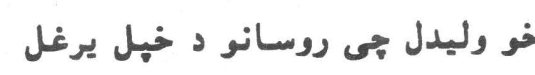
به انغـانستـان باندى د روسى

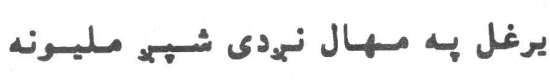

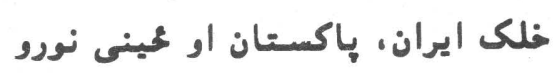

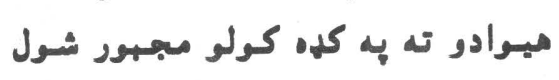

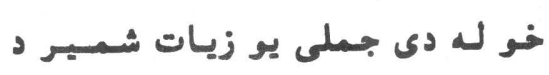

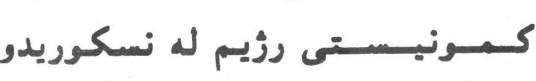
وروسته بيرته خبله كورو ته راستانه

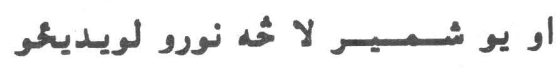

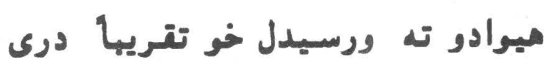

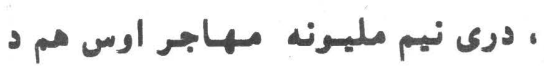

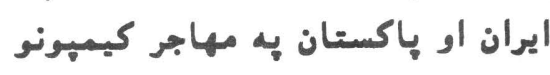

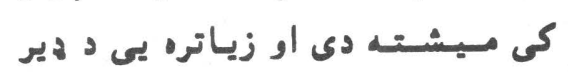

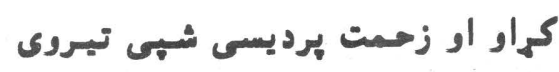

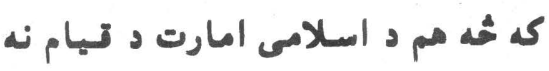

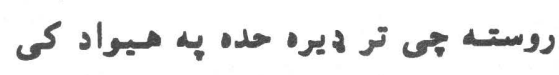

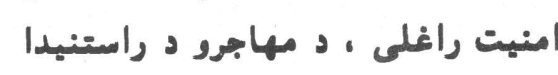

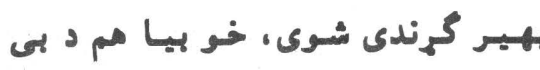

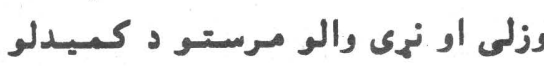

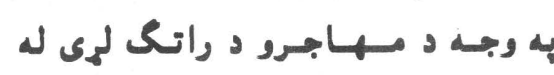

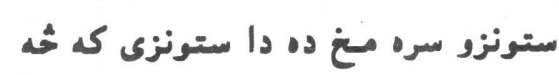

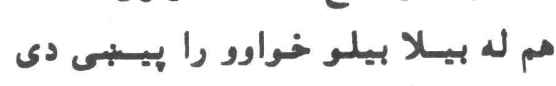

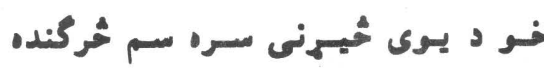

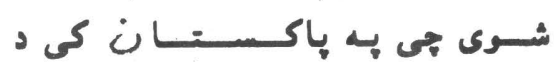

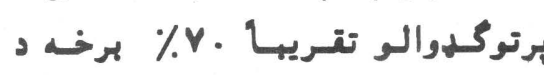

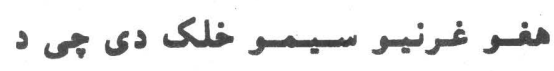

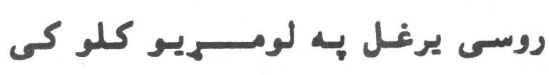

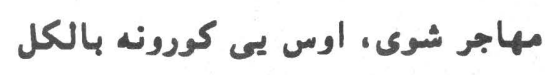

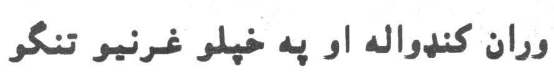

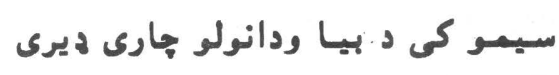

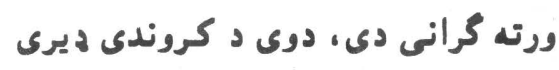

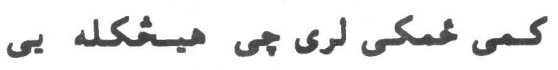

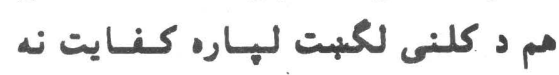
كوى او نه به خبلو كلبو كى د كوم بل كلي

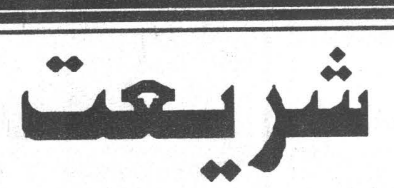

\section{An irys}

: هـ ليكوال هيثت تر نغر لاندي :

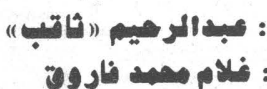

هتأسيس كال

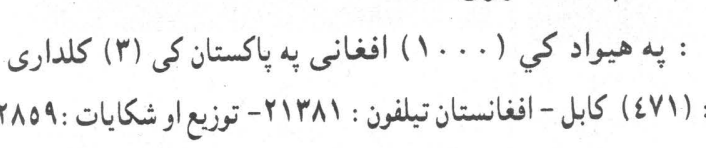

المارتي

مارتي مطبعه :

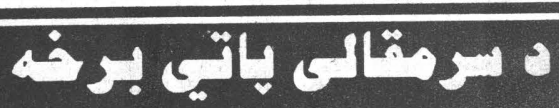

دمدرسى، كتابتونونه او مطبعى د جكهو به اور سوى ، وران

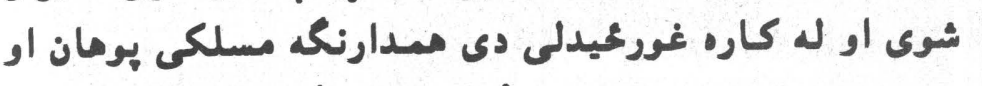

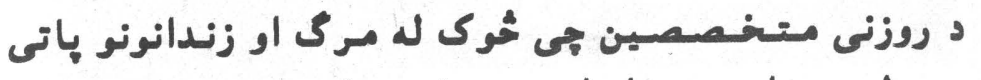

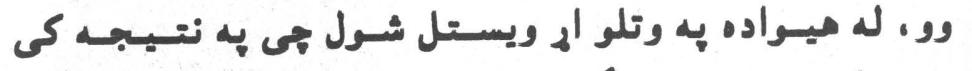

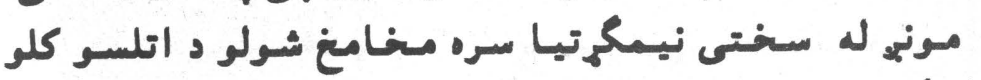

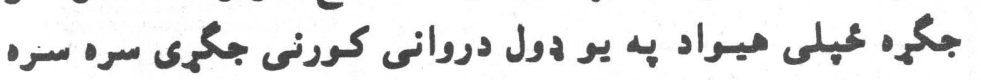

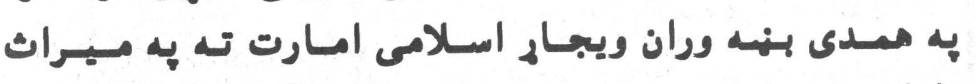

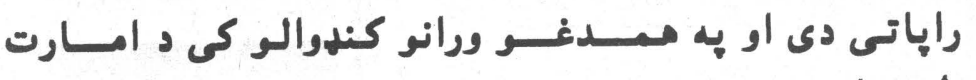

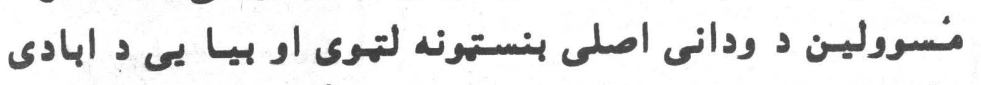

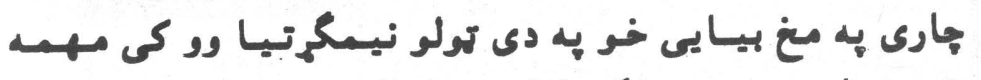

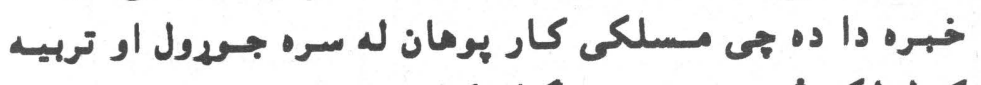

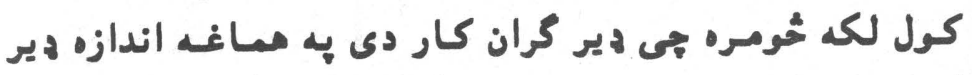

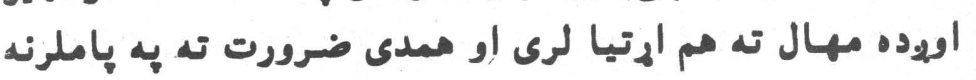

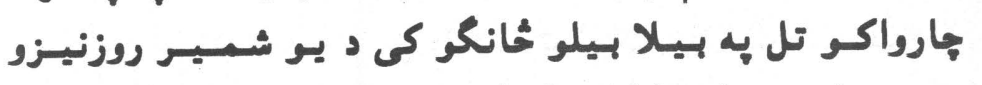

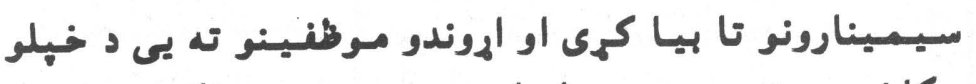

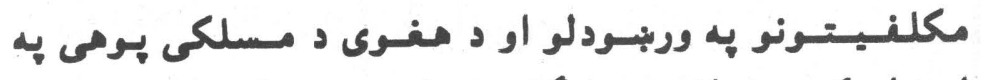

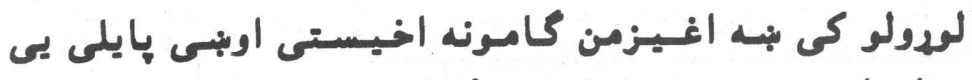

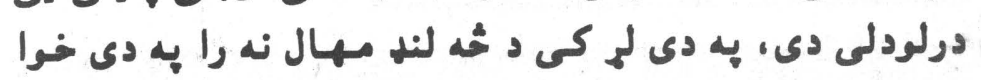

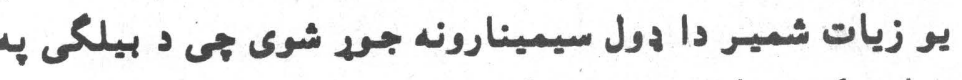

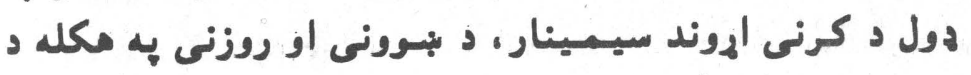

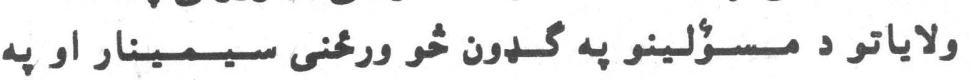

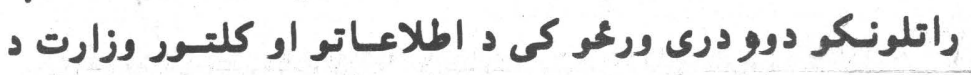

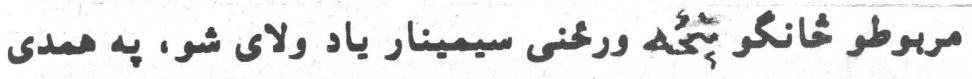

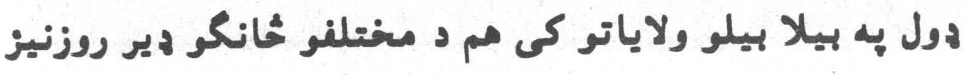

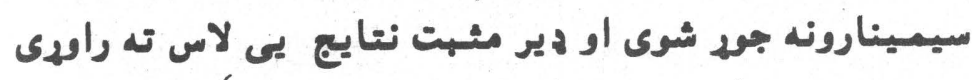

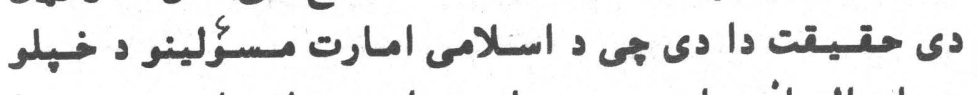

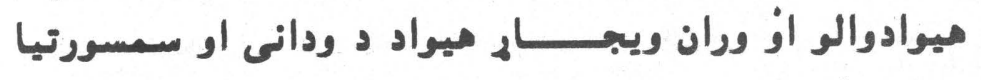

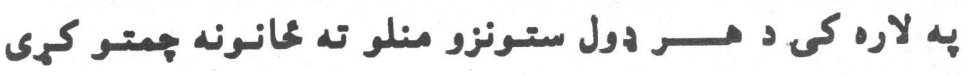

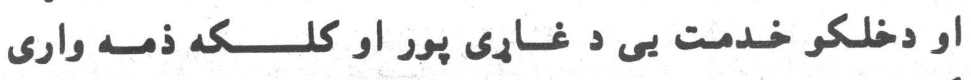

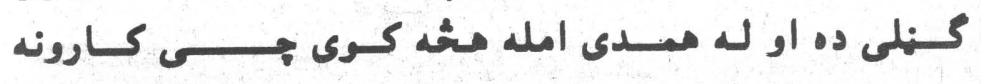

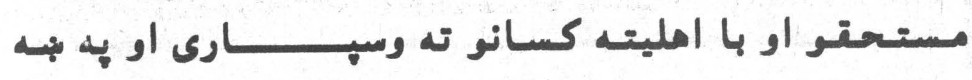

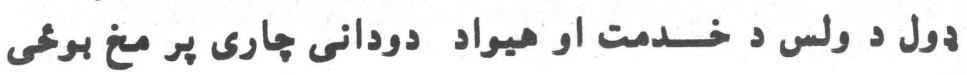

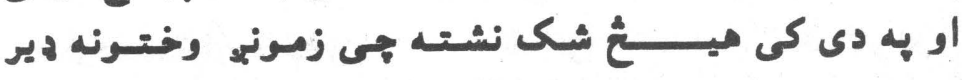

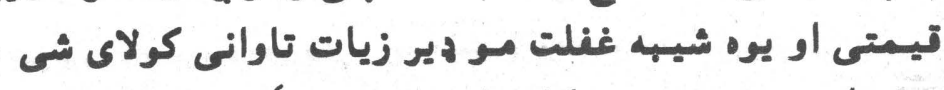

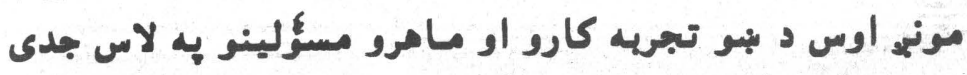

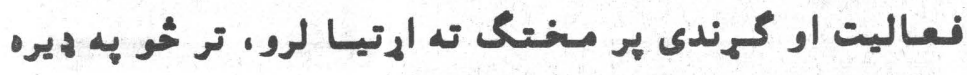

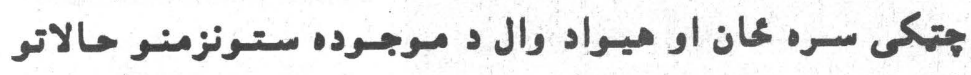

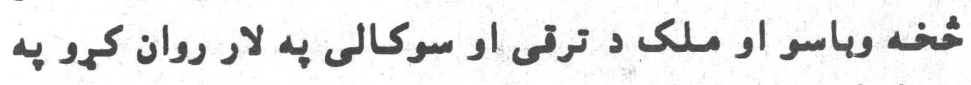

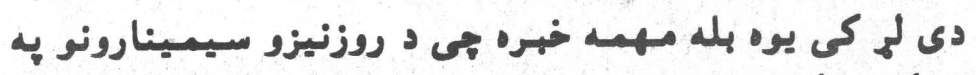

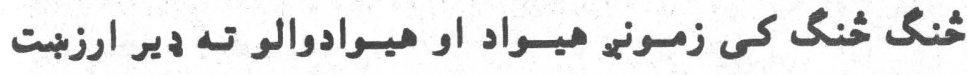

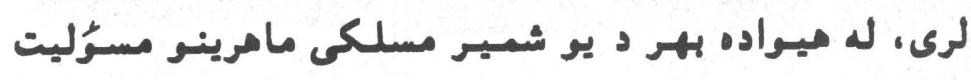

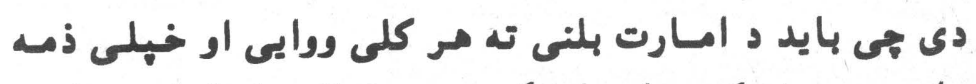

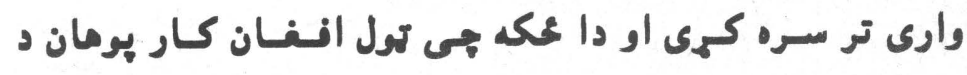

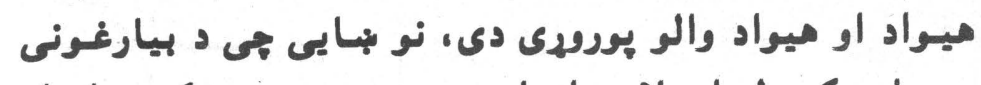

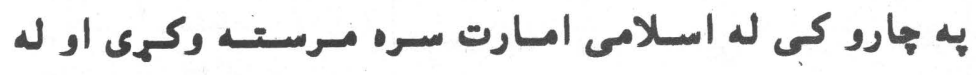

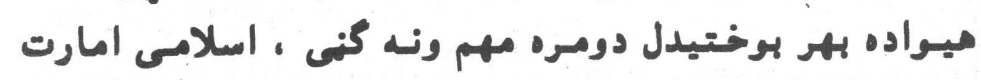

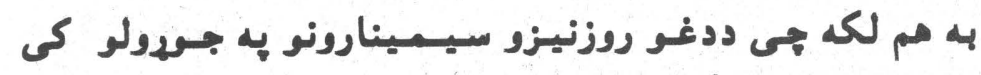

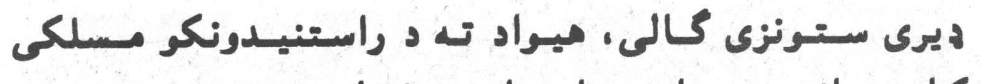

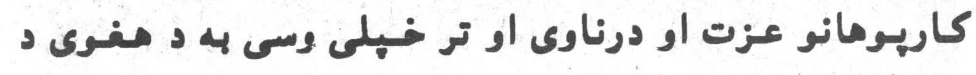

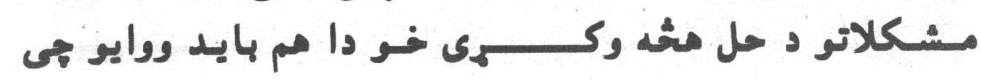

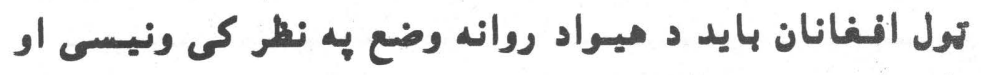

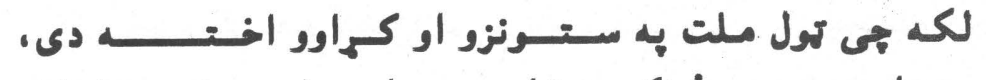

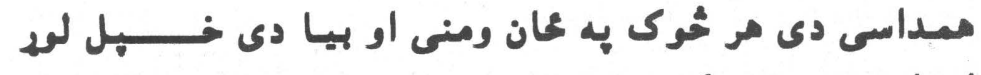
ارمانونه تعقيب كرى. 


\section{$\Delta$

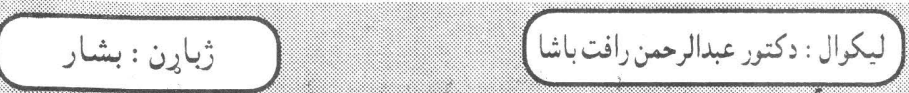

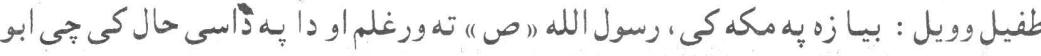

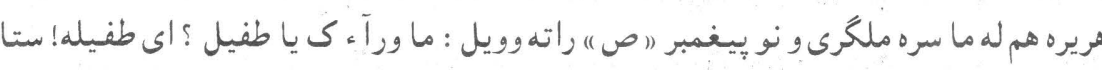

ما وويل : زرونه دى جى يردى ورباندى يرتى دى او سخت كفر دى اوسر كنبى او گناه يه دوس

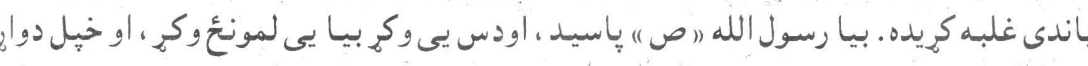

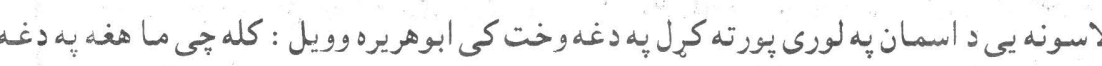

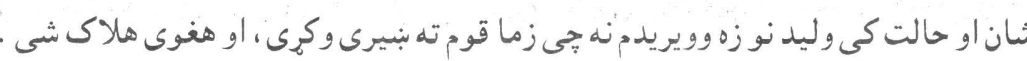

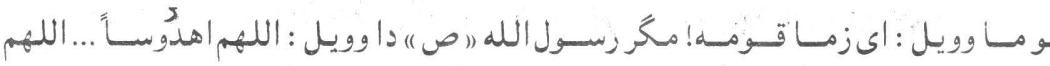

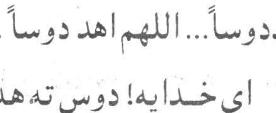

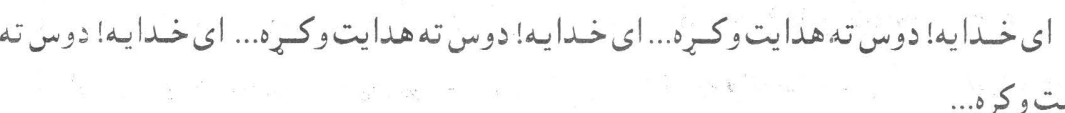
بيا يتى طيره

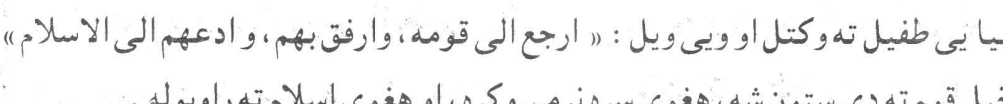

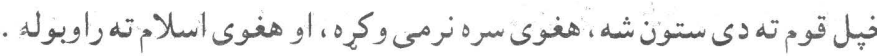

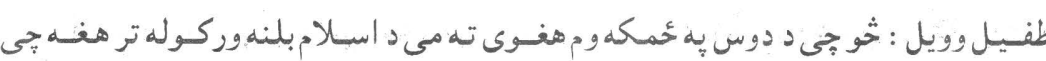

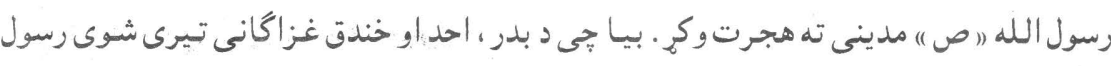

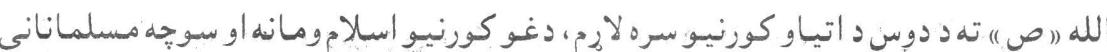

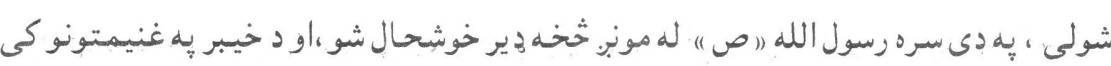

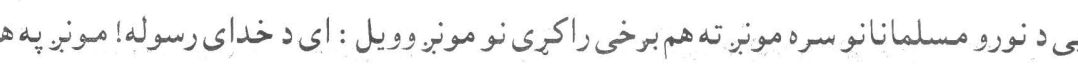

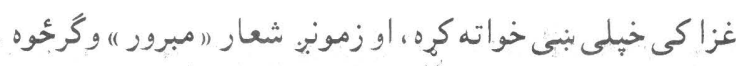

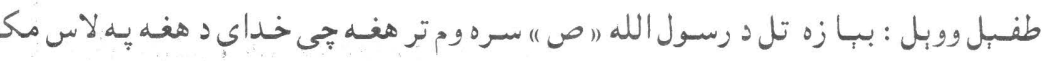

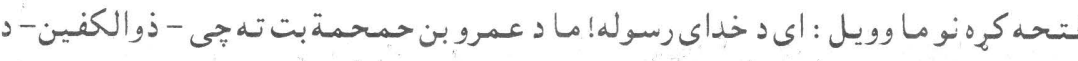

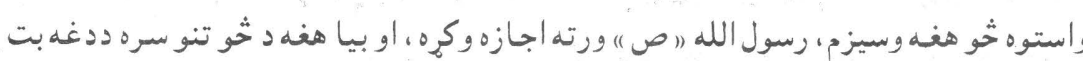

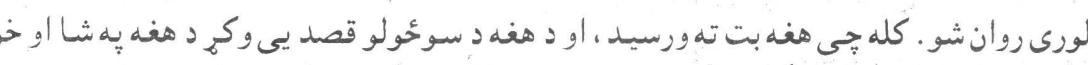

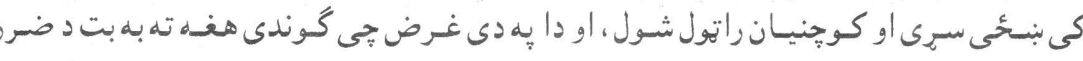

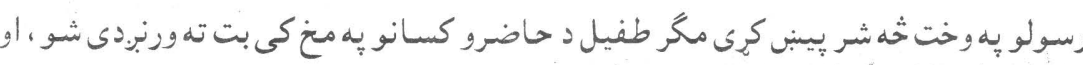

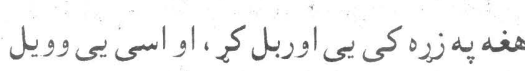

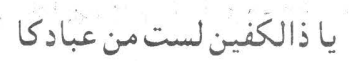
ميلاد نا اقدم من ميلادكا

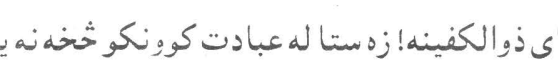

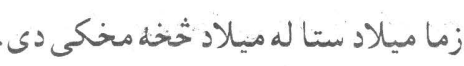

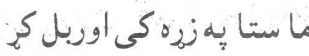

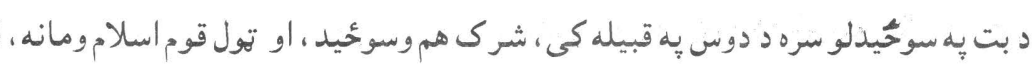

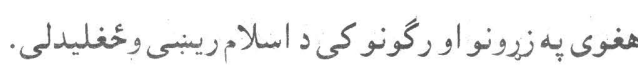

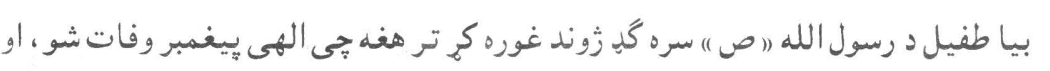

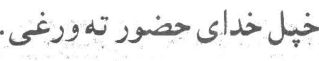

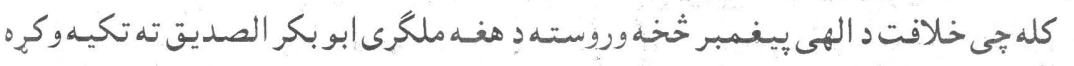

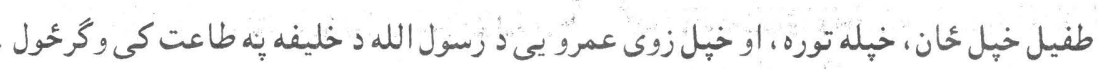

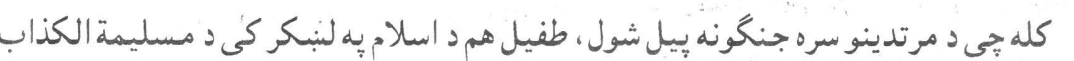

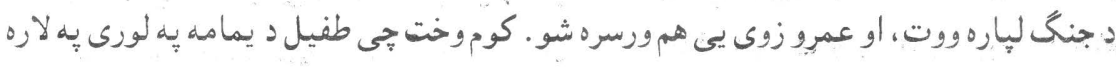

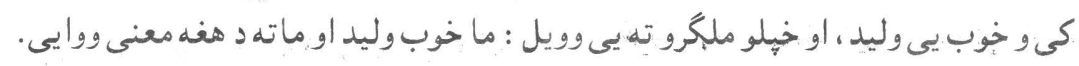

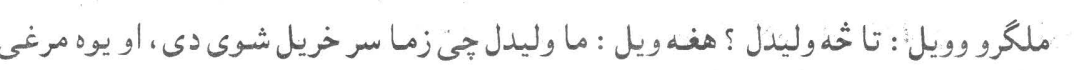

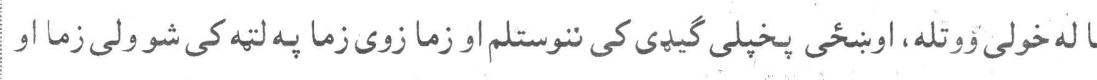

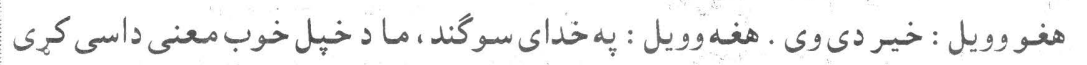

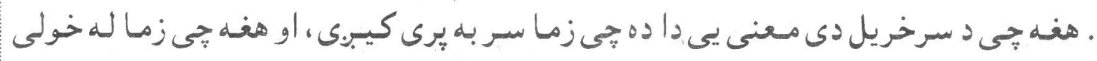

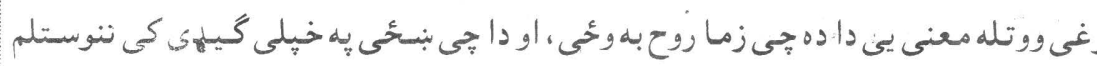

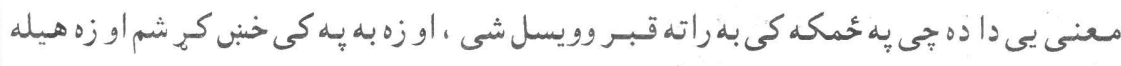

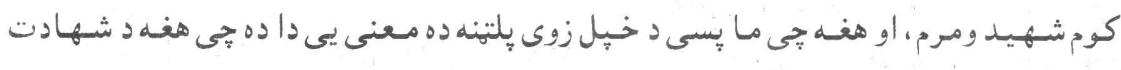

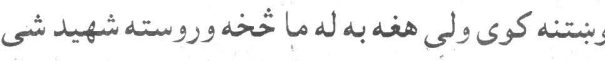

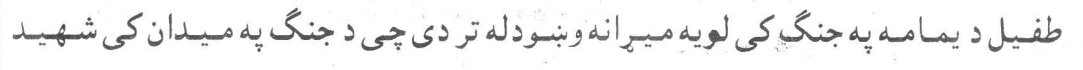

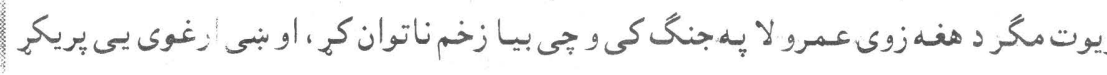

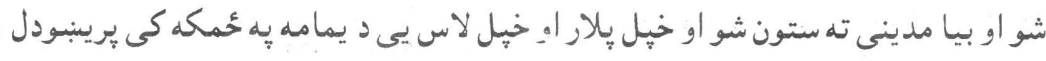

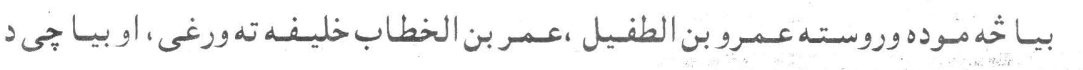

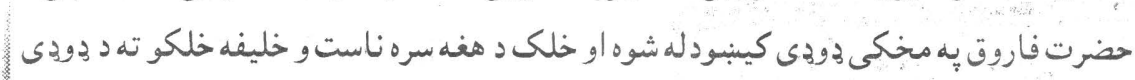

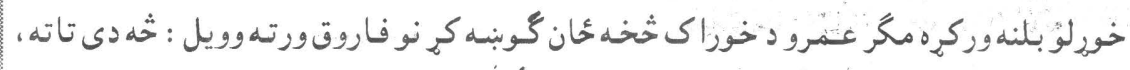

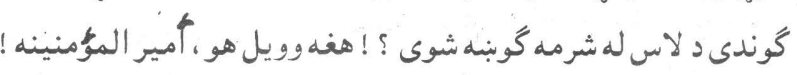

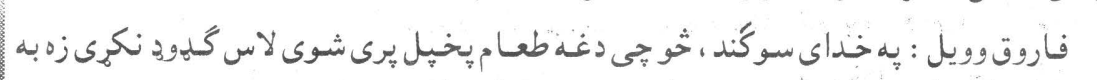

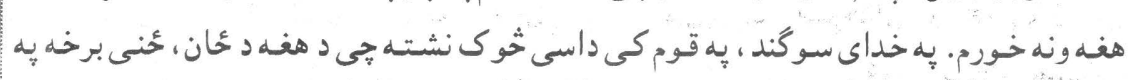

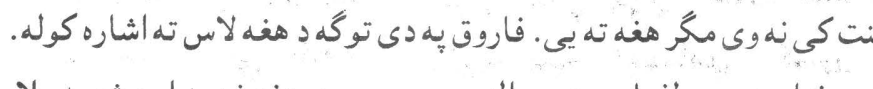
د اصحابو د رونل يلوشي

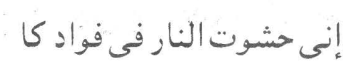

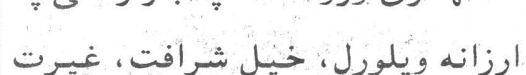

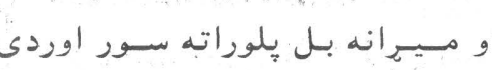

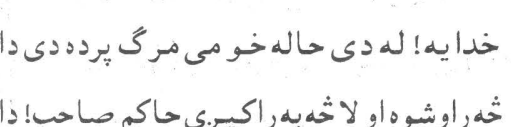

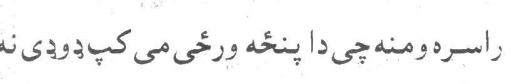

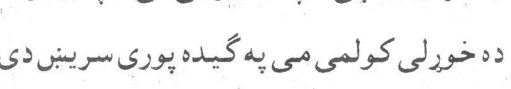

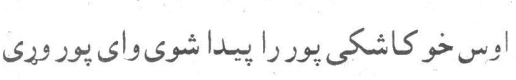

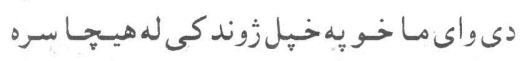

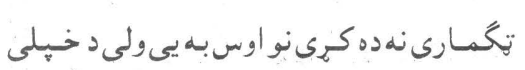

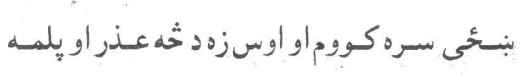

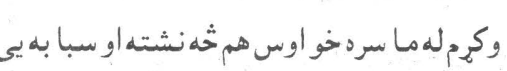

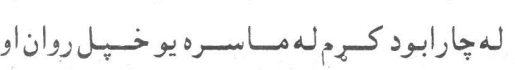

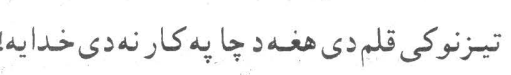

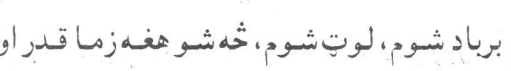
عزت اوخهشوى هغهزما هلى بحلى اوزما هاغه

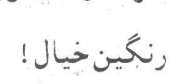

حيكم يى باك ليسونى كي اوذيربيى وثزل او

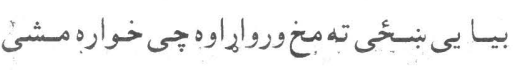

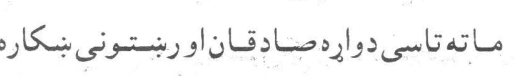

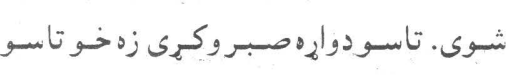

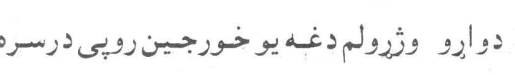

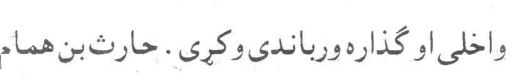
وايى جى ما به هماغه اول مهال دا سرى ويبرانده جي د/ابوزيدنامتو اديب دي مكرخهم مي نهويل كله جيى دوى دواره روانشولنولنو حاكم تهمى ايله

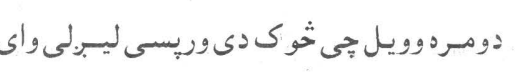

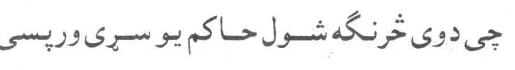

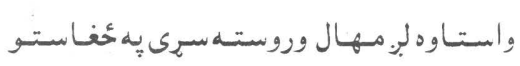

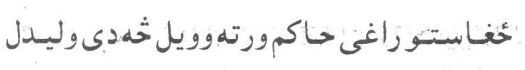

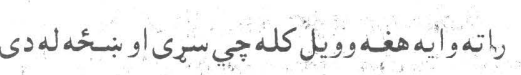

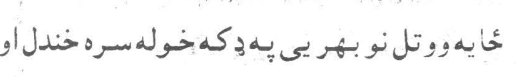

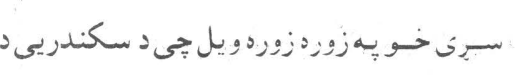

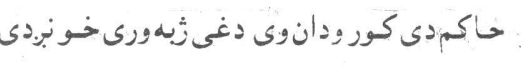

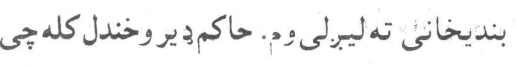

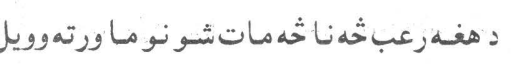
جى حاكم صاحب دا سرى ابوزيدنامتو اديبوه

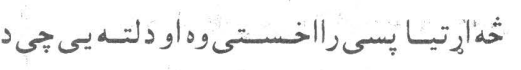

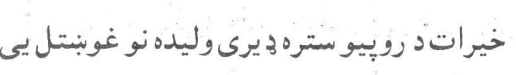
جي ستردونده ورنه يوسى تاهم همداسيى وكريل حـاكم نور هم حسونب شـو او بيـايى

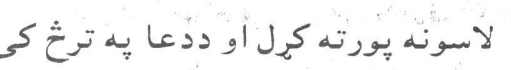

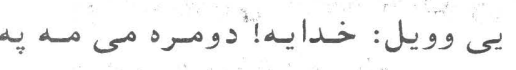
غصه او بيسواكه كوى جحى ابوزيد غوندى غورن اديب بنديخانى تهو ليبرم.

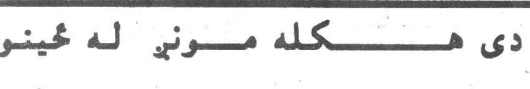

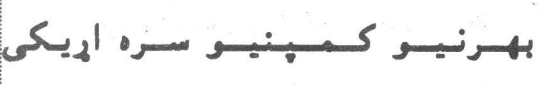

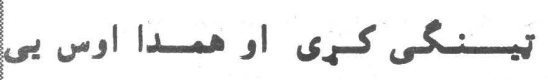

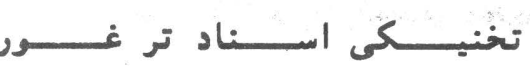

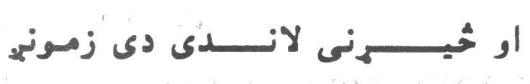

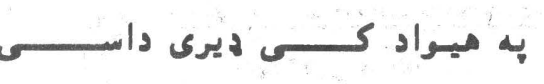

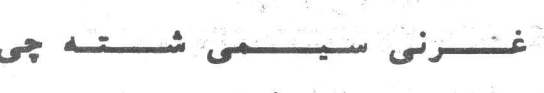

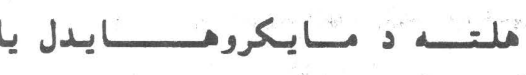
Smale Hydropower دستخاوو د نصبهولو امكسـانات شتب

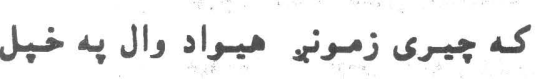

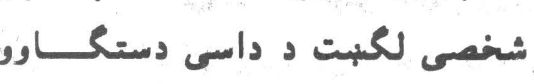

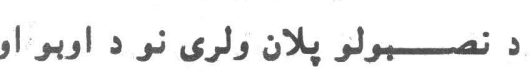

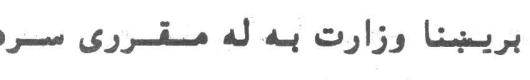

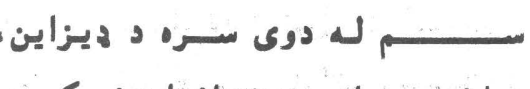

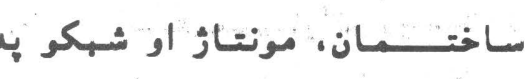

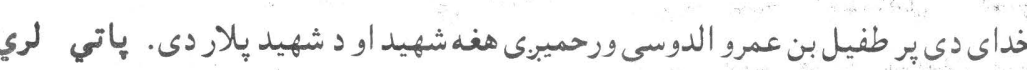

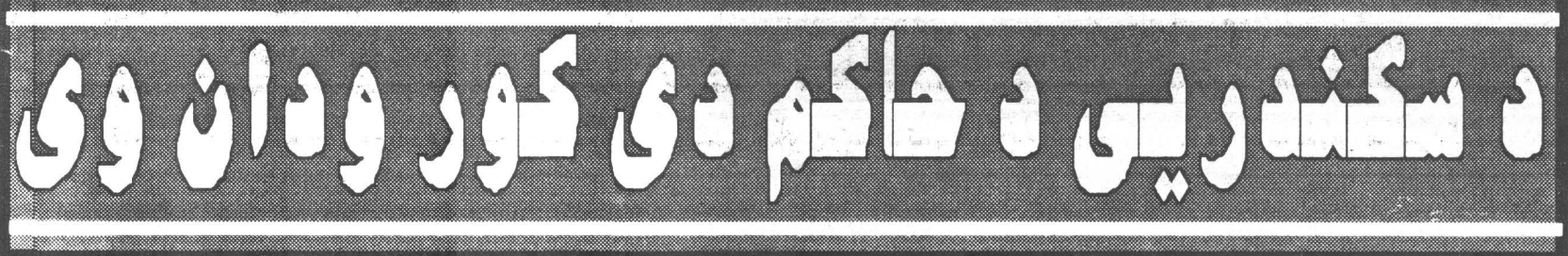

دى له لو.بى مره واى درى كلن مـاشوم:

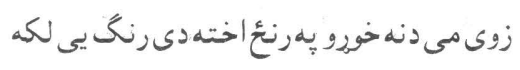

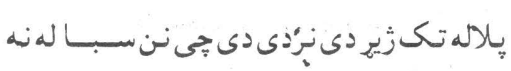
خورو ومرى.

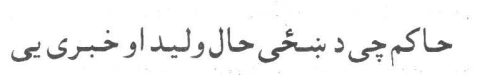

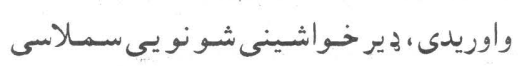

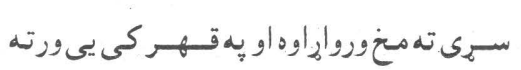
وويل: وارستادى سمى خبرى وكره اوربنتيـيا

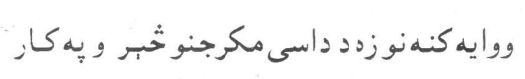

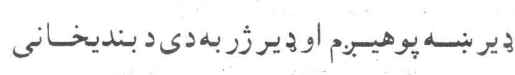

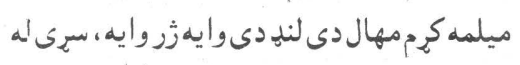

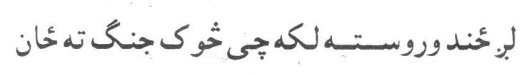
تياروى يه خبرو يبل وكي جيى حاكم صاحبهد

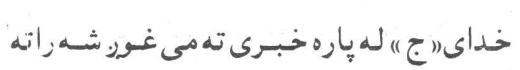
حيرانبهشى او كيداىشى جيى راتهوخاندى او

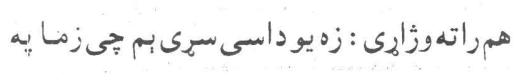

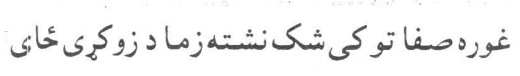

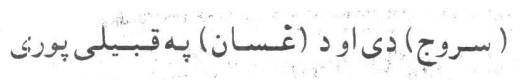

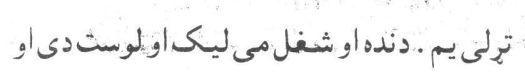

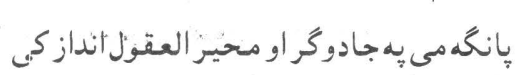
شعر ،خطابه، نظم اونثر دى، زه جِى دف فصاحت

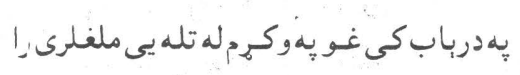

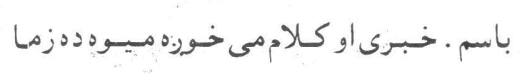
هـزولى د سسون لركى راتولوى اوز زه له الفـاظو

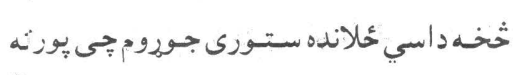
خيزى او خلك لاره برى وينى يووخت به مـانه

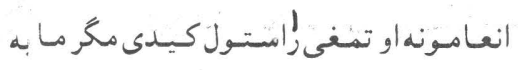

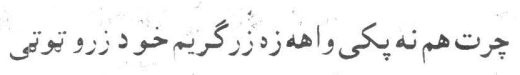

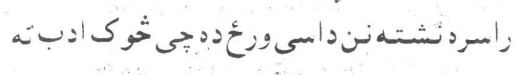

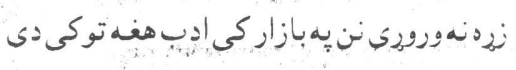

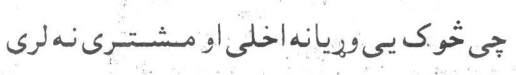

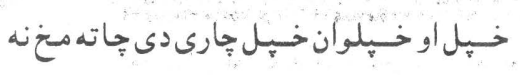

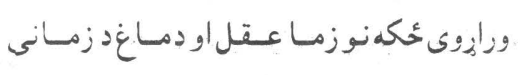

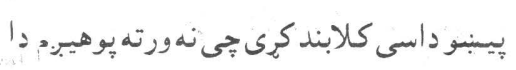

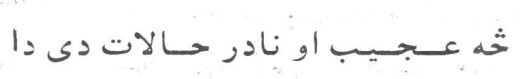

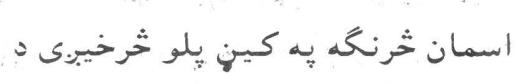

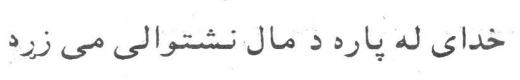

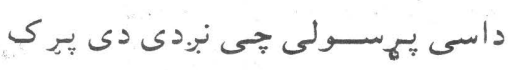

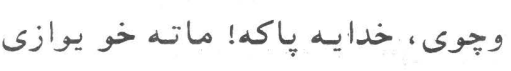

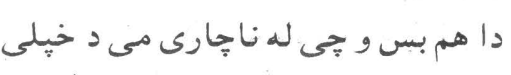

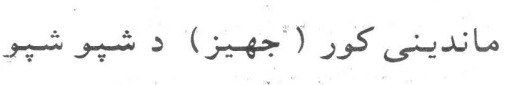

دى زياتوى : د هيريبنا د انرؤى

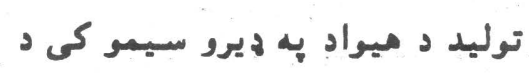

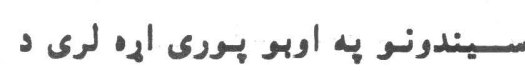

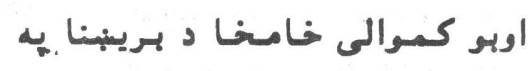

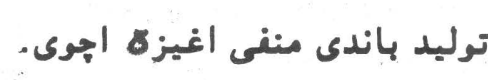

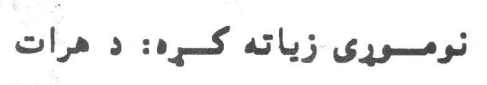

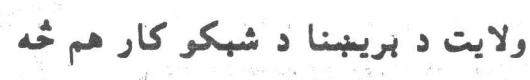

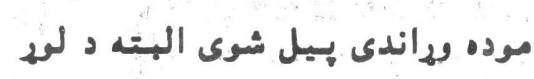

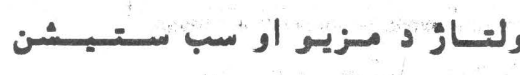

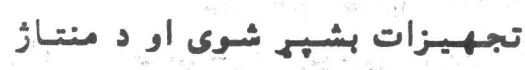

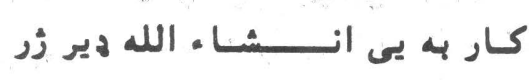

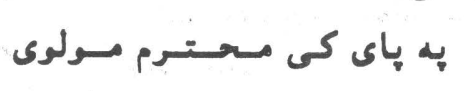

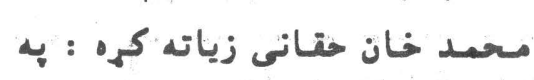

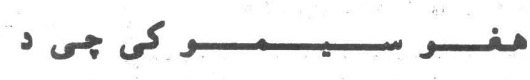

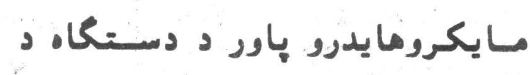

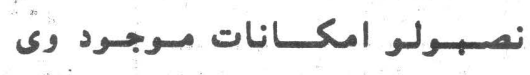

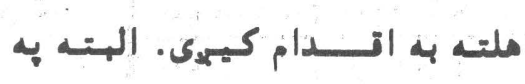

ملا محد اصغر عاكف

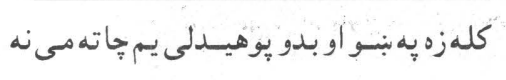

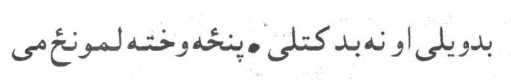

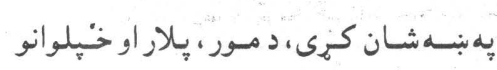
درناوى مى كـى او هـــد الامل وجى زميساد

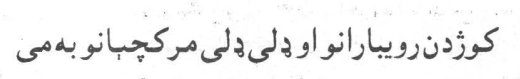

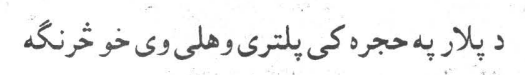

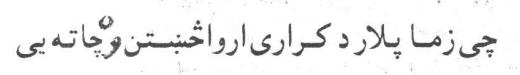

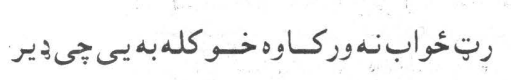

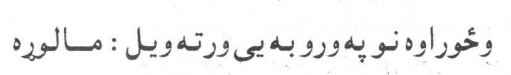
كرى جي خ خبلى لور كوزدن له يونبـهاديب

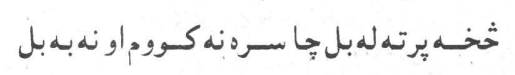

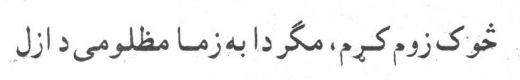

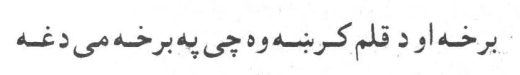

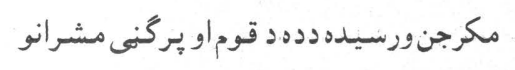

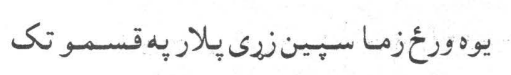
شين كي جيى دادى ستا شرط يوزرهو ، دائوان نبهه اديب|وشاعر دى كستب او هنر خاونددى

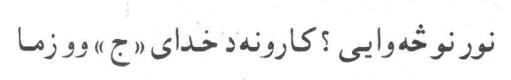

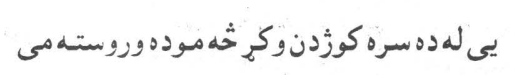

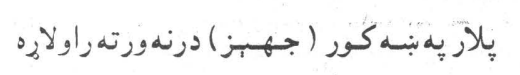

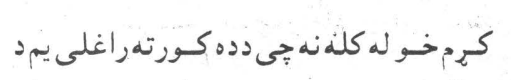
روزى دروازي رايسى تئلى شوى دى يه سيورنه

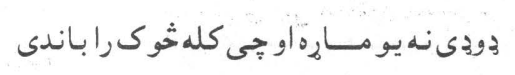
مهبريانهشى اوخهراورى نو هغهد اختر ورئ

وى تر يري مودى خوزما دكور (جهيز ) يه

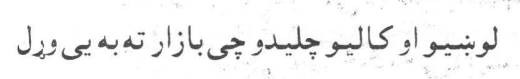

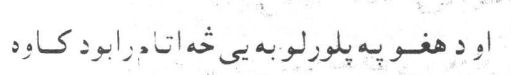

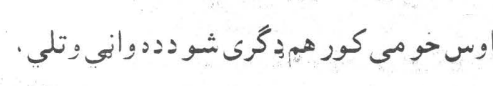

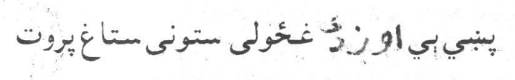

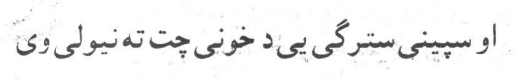

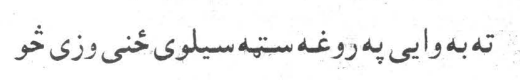
خلمى مى ورته ويلى جى سـريه ولاري.

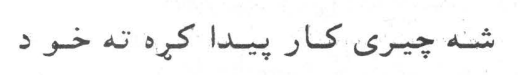

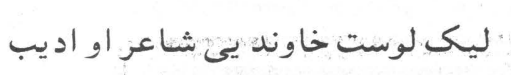

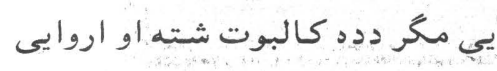

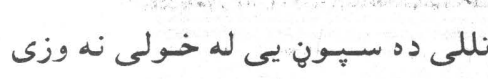

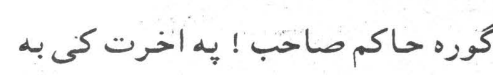

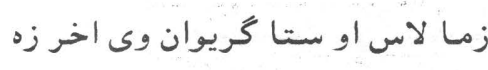

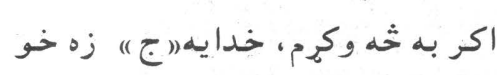

\section{د بريبنينا مؤسسي عمو مي رئبس محترم...

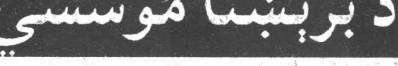

شبكو او ستــــنونو د تنطيم به

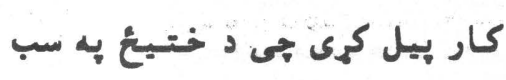

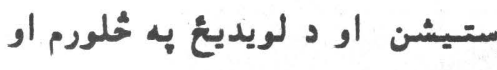

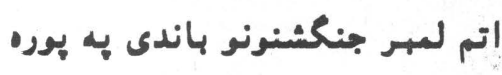

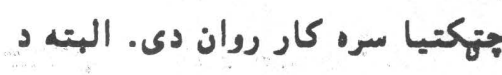

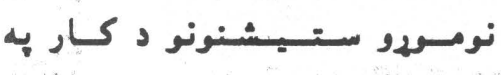

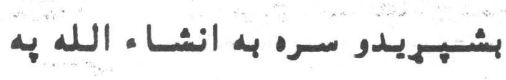

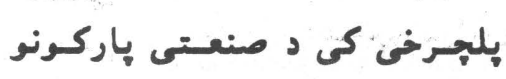

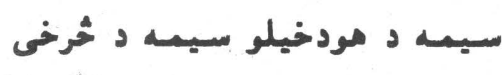

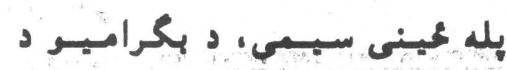

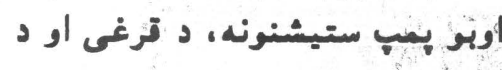

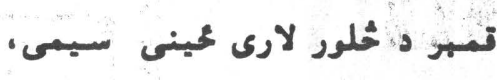

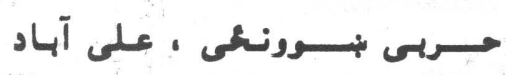

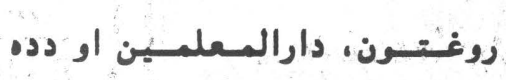

هوخمن شيى

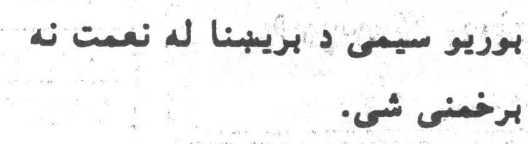

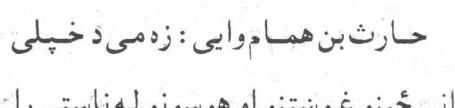

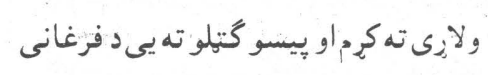

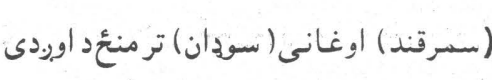

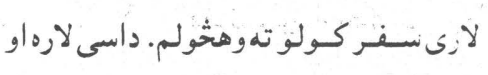

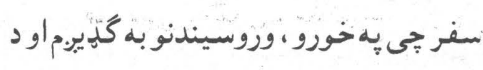

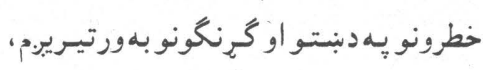
خو د ادب بوهانو د خولى هغه خبره مى هم يه

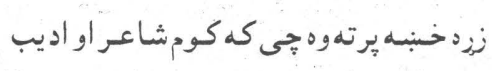

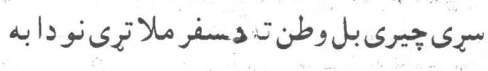

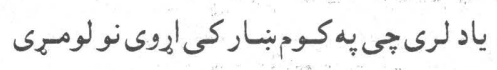

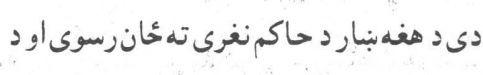

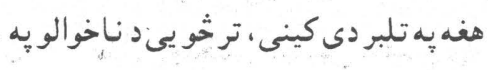

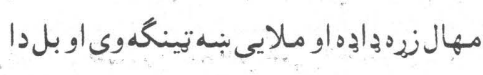

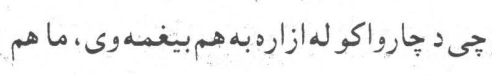
د هغوى دغهادب ، دئمان لاربنود او د خهيلو

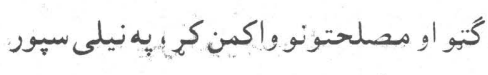

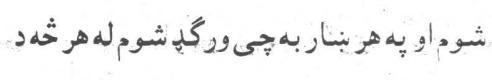
مخهبه مى د هغه بنسار حاكم ته لارهوربرابره

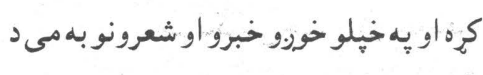

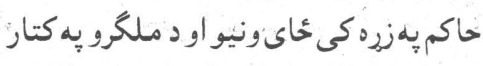

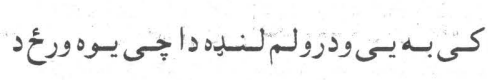

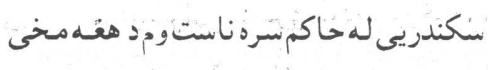
تهد صدقو او خيراتونو دورييـو هغه كوته

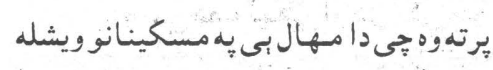

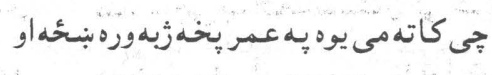

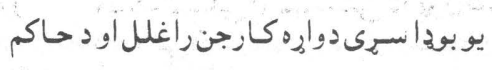

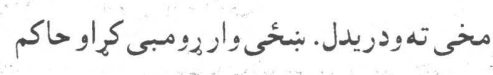

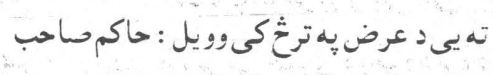

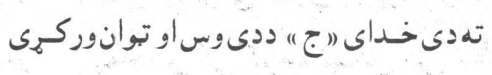

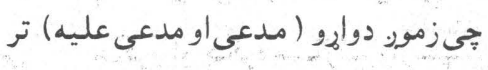

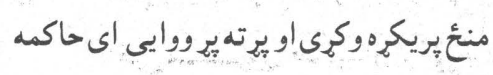

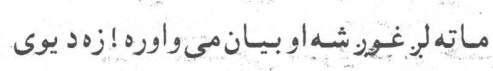

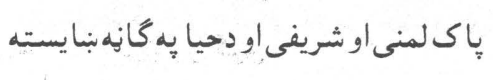

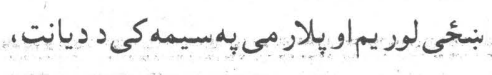

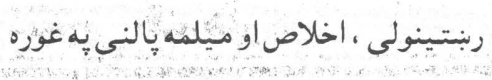
صفتونو خلك يِيزنى، ماماخيل او كاكاخيل مى دوارد خواوى به قومكى به بنبو ياديري. زه ددغى كورنى يه ياكى غولى زيريدلى او ستره

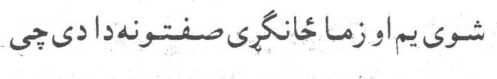

شريعت : تدرمنو لوستونكوا

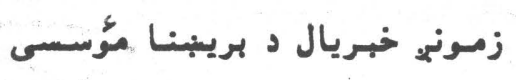

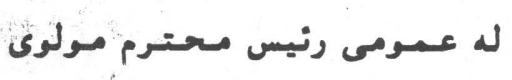


كثراً خلكو به زما د تمى يه خلاف ويل

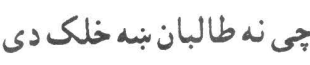

مامورين به خلاص نره افغانستـان تـ

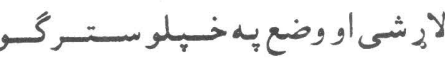

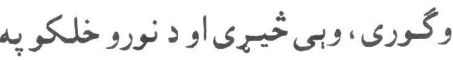
تيره بيا د غرضى خلكو يه خبرونو ونه

غوليبرى. دى وايى كه جيرى دغه كار

وشى دى يقين لرى جى بنديزونه به لرى

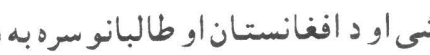
مقابلى به هُاى د ملكُرتيا لاره ونيسول

مـايك هوبر زياتوى : د طالبـانو

هدف دا دى جى د تولو گاونديانو ، تولو

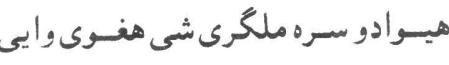

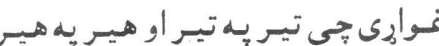
كرى ، يه تيرو جنجالونو كى ئان راگير

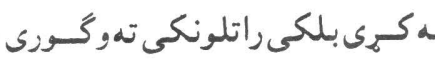

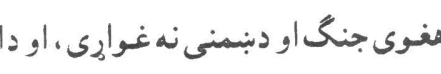

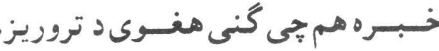

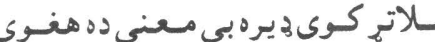

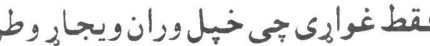

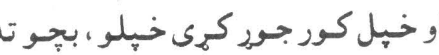

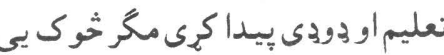

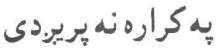

امسريكايى خبـريال مـايك هوير

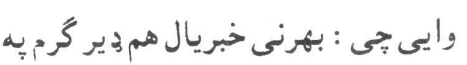
دى نه دى جىى افغانستان او افغانان سم

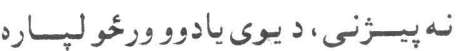

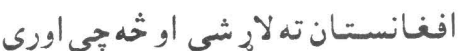

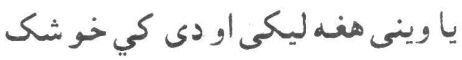

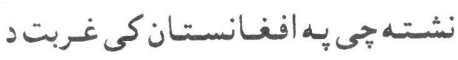

جنگ تباهى او نيسيتى وا تول شـيـان

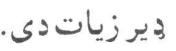

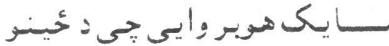

خبريالانو بى خبرى دومره 30 يره 20 جي

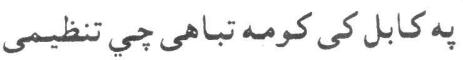

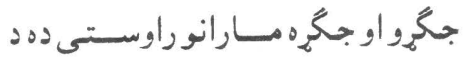

هنى مسسـوول طالبـان بولى او د نيى

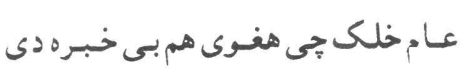

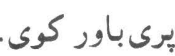

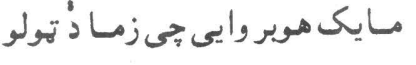

خبرو معنى دا نه ده جى طالبـان توندنه

دى او يا دا جِى يه خلكو باندى سختى نه

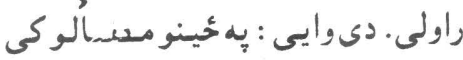

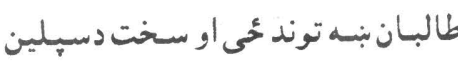

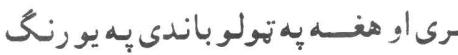

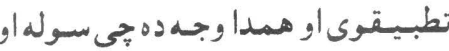

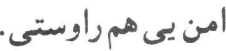

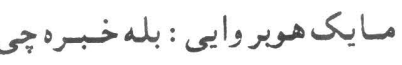

زما خوبنه شوه دا وه جيى يـه افغانستـان

كى اوس تشـريفـات نه شـتـه ، هرخوى

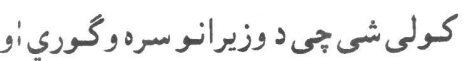

خبل عرايض ورته وراندى كئى

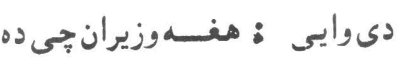

وليسـل داسى نه بنكاريدل لكهدوزيران

جى وى او يوى خبرى جى 3 ير حيران كئم

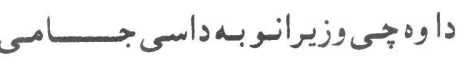

اغوستى جيى نور خلك يى اغوندى او د

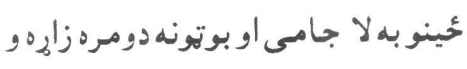

جى د عادى خلكو نه به يى جندانى فرق

هم نه كيده

مـايك هوبر وايى : يو شى جيى زن

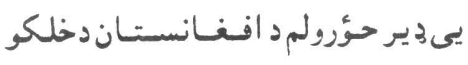

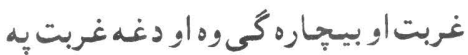
تيسره د هغسو بنديزونو لهامله لا بسى

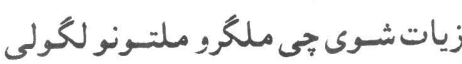

مـايك هوبر وايى : خو خلك ددى

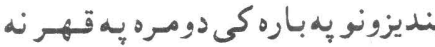

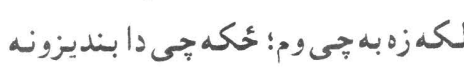

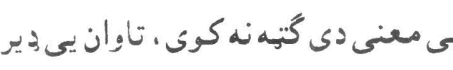

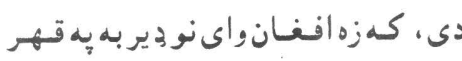

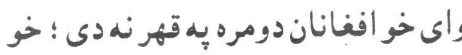

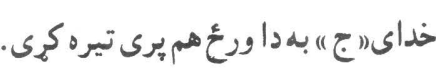

مسايك هوبر وايى : دده هيله دا ده

جيى نه يوازى د امسـريكا بلككى د نرى : دوند

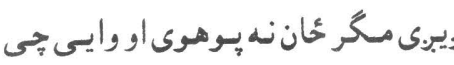

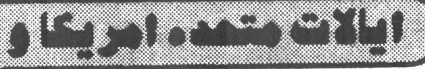

كثور معوار ميكند.

به مسرجب اين توانق كه نتا منوز مبكر

به تصويب كانكرس امريكا نرسيده،

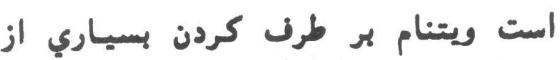

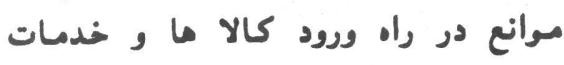

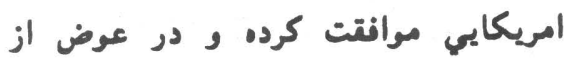

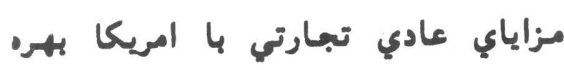
مند خواهد شمد. تمادي

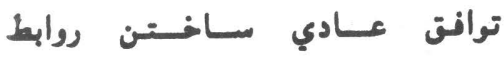

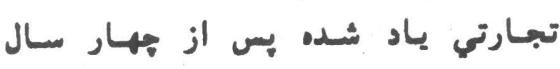

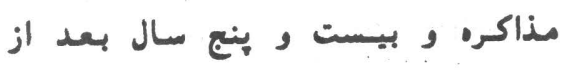

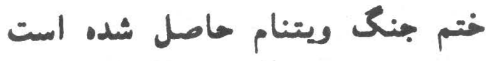

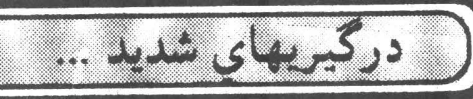

كه ميان قوماندان حضرت و توماندان قاري

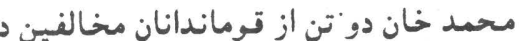

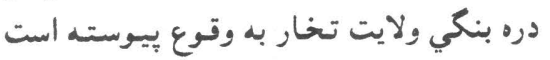

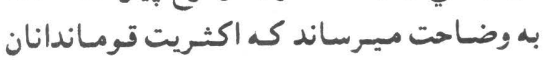

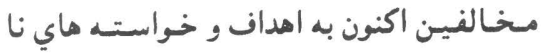

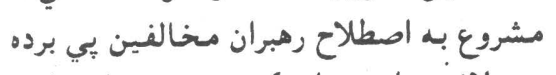

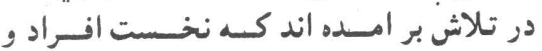

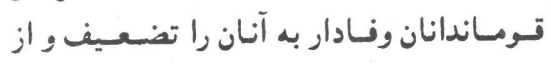

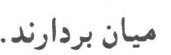

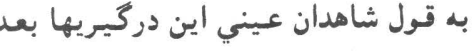

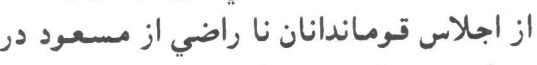

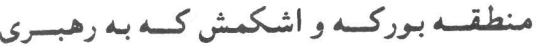

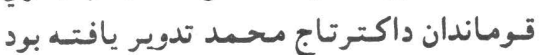
قوت خرفته است.

منبع مي افزايد : در اثر دركيريهاي تازن

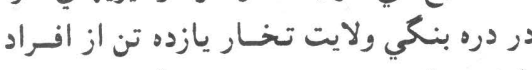

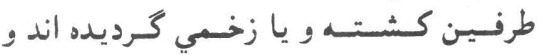

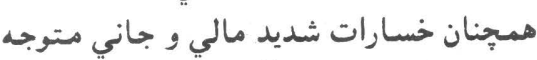

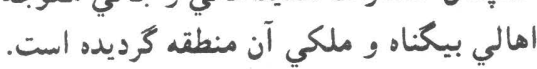

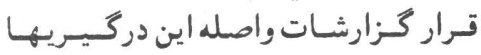

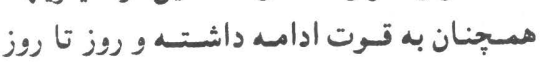
ابعاد و وسعت تازه بخود كسب ميكند.

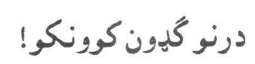

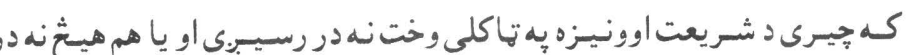

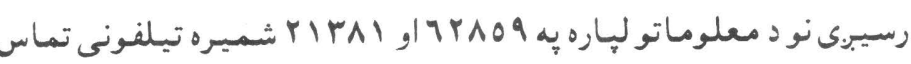

\section{SHARIAT ITEKLII}

Published by :

Islanic Emivate of Alghanistan

Chief Editor: Abdurrahim Saqeb

Printed by: Emierrtes Printing Precs

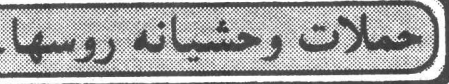

طبت خبر مذكرر مباهدين مسلسان

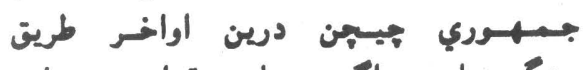

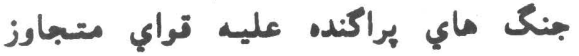

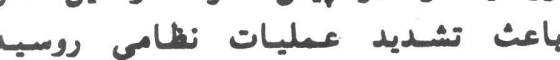

\begin{tabular}{|c|c|c|}
\hline \multicolumn{3}{|c|}{ ه كلهون بيه له هيواد ند بـر } \\
\hline 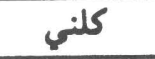 & شير" مياشتنى & ملك ملك \\
\hline RS400 & RS200 & باكستان \\
\hline SR.300 & SR.150 & دخليج هيوادونه \\
\hline US\$150 & US\$75 & ارويا او امريكا \\
\hline
\end{tabular}

مــــام وزارت زراعت و مـالداري و سـاير بـخش

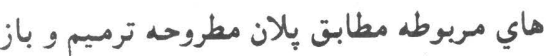

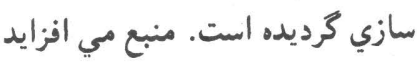

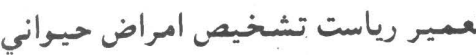

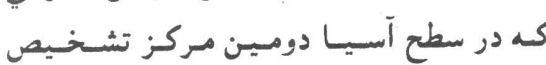

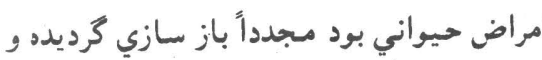
با امكانات ابتدايي و جلب كمكهاي موسسـات بوندات

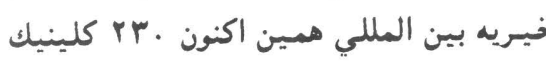

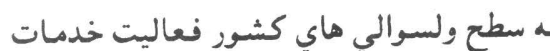

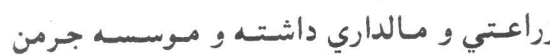

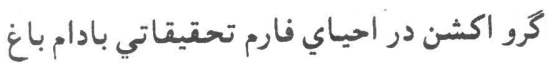

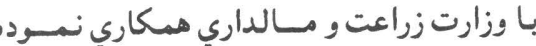

منبع تاكيــد داشت كهم ترمسيم باز سـازي

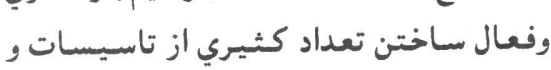

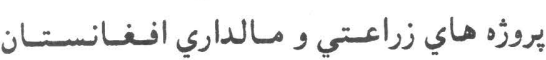
مستلزم كمهاي كشور هاي دوست و سازمان

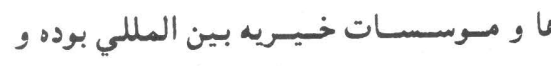

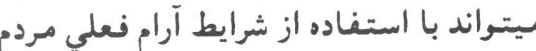

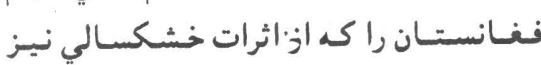

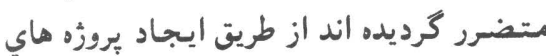

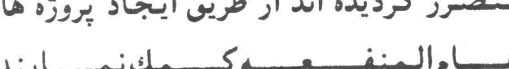

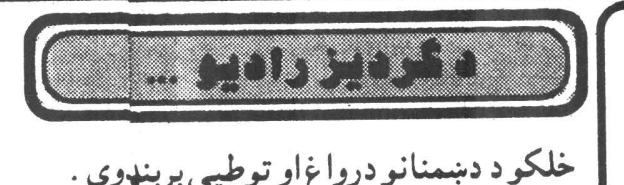

خلكو د دبنمنانو درواغاو توطيى برينهوى .

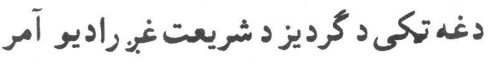

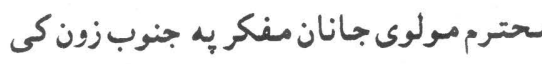

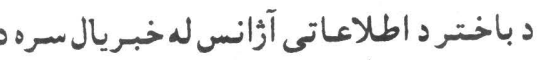

يوى مركى به ترخ كى ثركند او زياته يى كره :

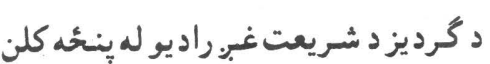

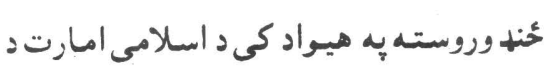

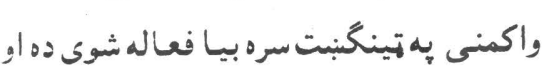

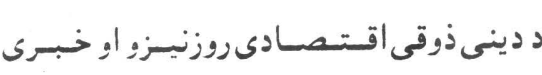

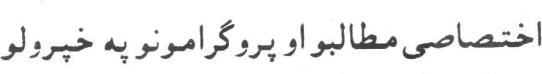

سره يى وكولاى شول جيى د خلكو د ذهنونو بـه

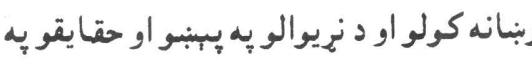

منعكس كولو كى ستر او اساسى رول ولويوى.

دُ كرديز شريعت غبر راديو د روان كال يه

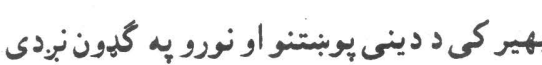

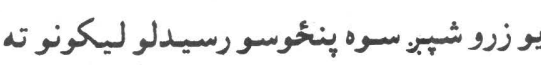

يحواب ويلى او يه دى ترتيب يـى له خلكو سره

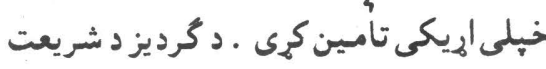

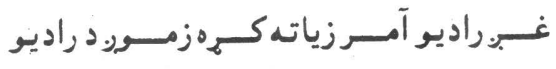

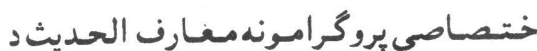

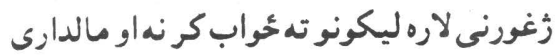

نيوونهاو روزنه تاسى او ستاسو روغتيا خيرى

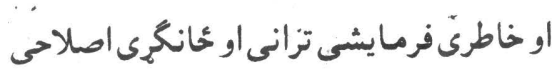

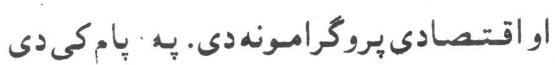

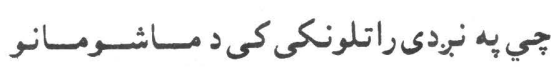

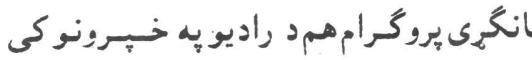

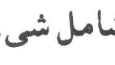

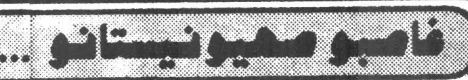

دغه تانون هوه احسد طهى وريل

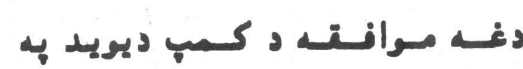

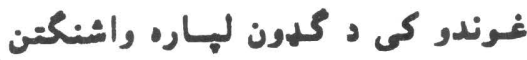

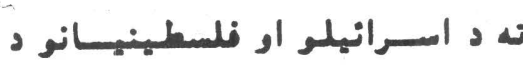

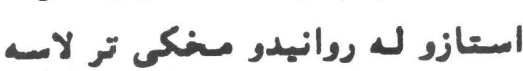

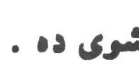

ده د خبلو اطللاعـاتو مسر هينه

افشا نكره خو ويلى يس دى خهى دغه

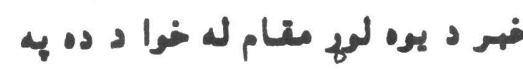

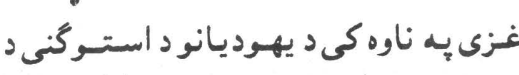

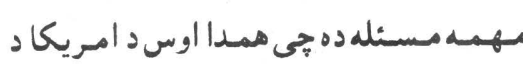

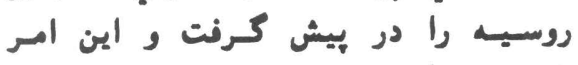

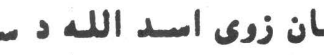

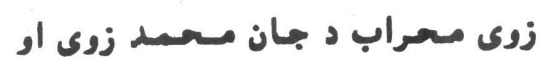

\section{ميث شريد}

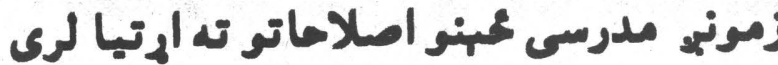

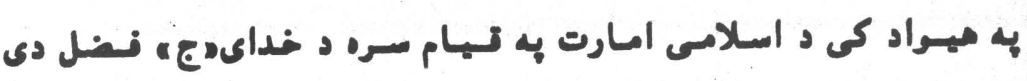

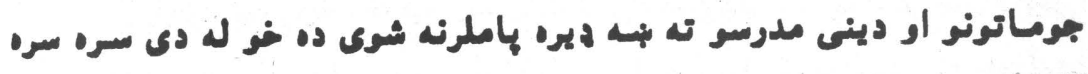

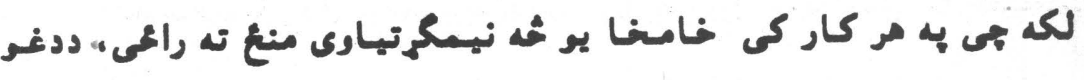

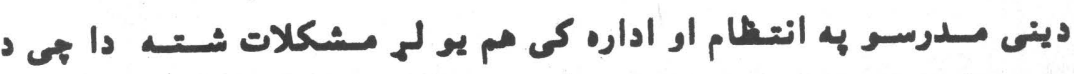

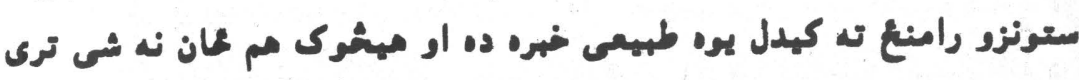

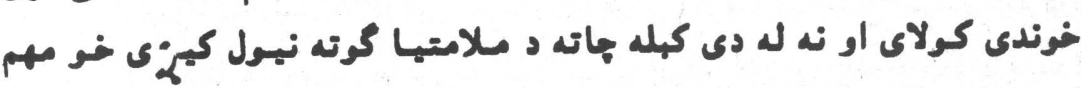

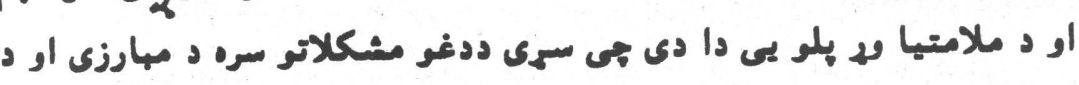

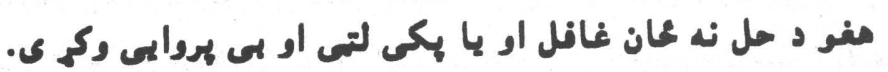

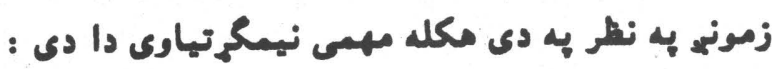

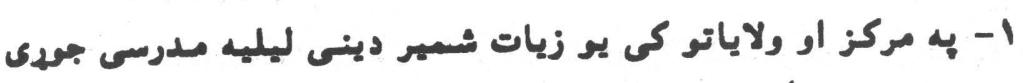

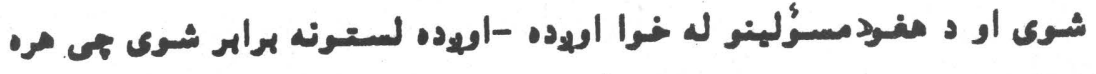

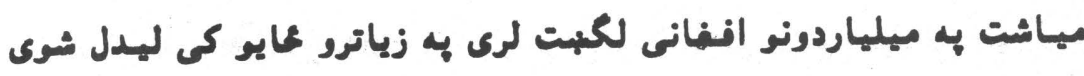

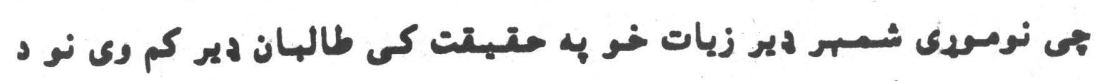

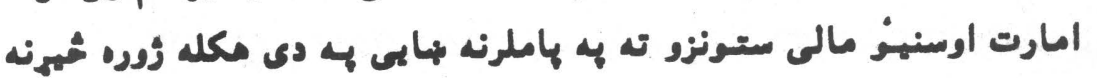

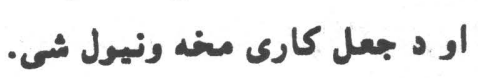

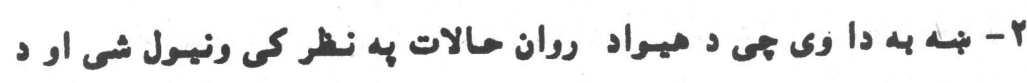

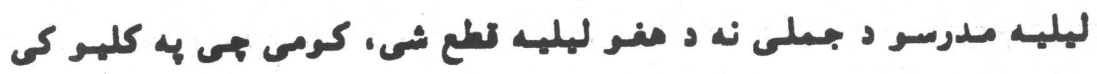

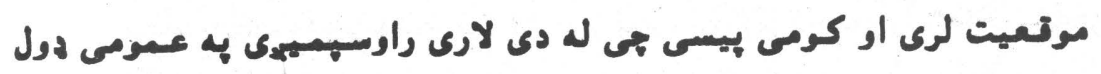

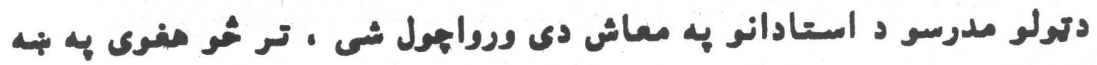

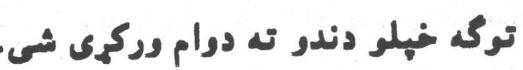

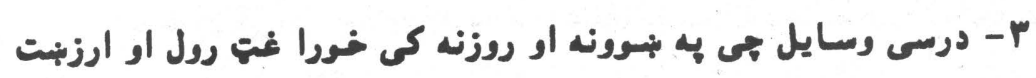

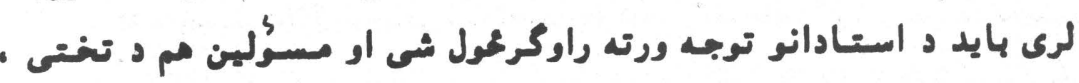

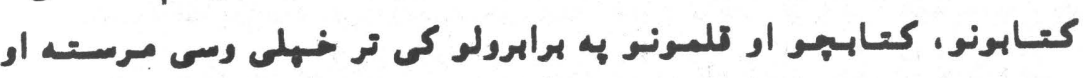
ملكرتيا وكرى.

ع- جمه شوي درسى نصاب دى دو تهريه كارو امتـادانو او د تعليم او

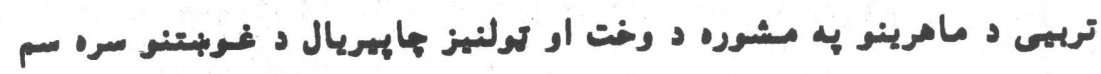

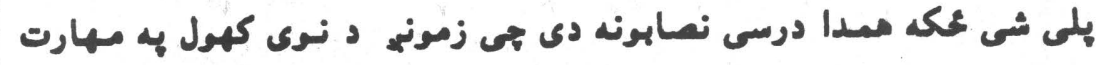

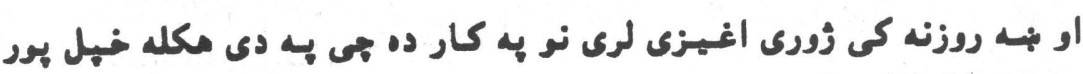

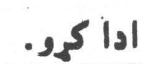

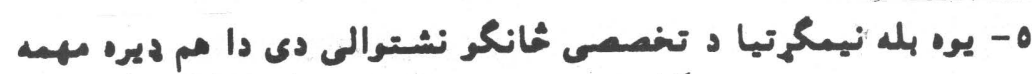

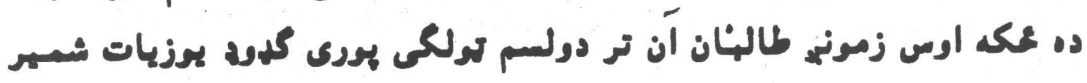

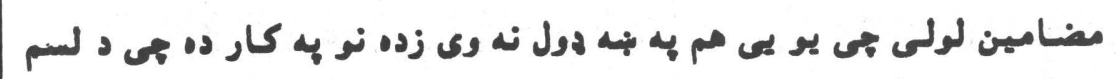

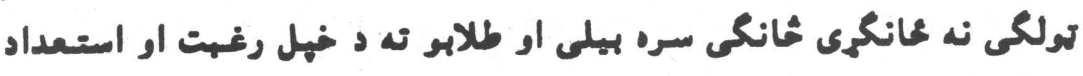
سره سم وخت وركهى شم.

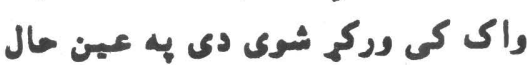

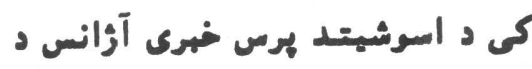

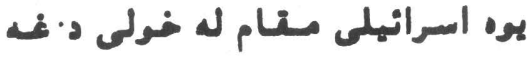

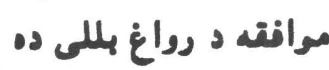

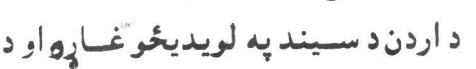

بنارگوتو برخليك د فلسطينيانو او اسرائيلو

تر منيخ د سولى د هغو خبرو يه اجندا كى يود بردي

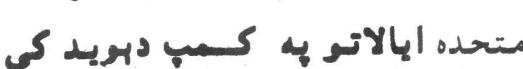

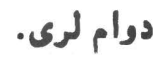

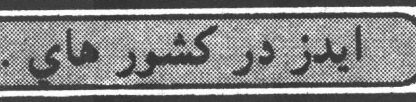
متحده امريكا انعام يانته است

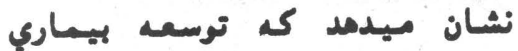
ايدز در كثشور ماي روبه انكثان

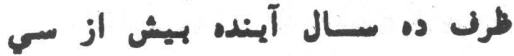

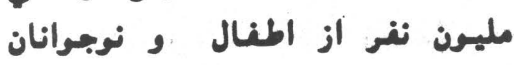

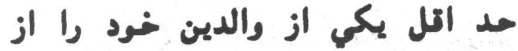

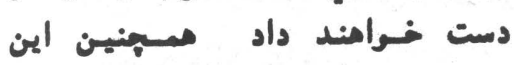

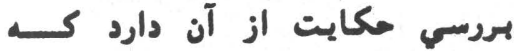
مصيت ناشي از شيوع بيداري ايدز به مراتب از مرقى و مير جلو تر ميرود.

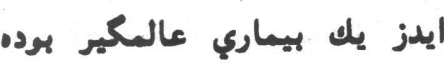

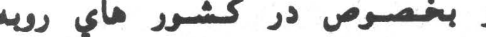

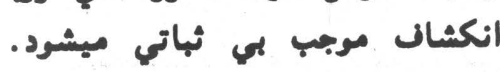

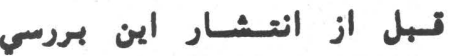

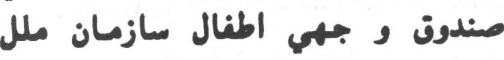
متعد طمي كزارشي از كشمود ماي

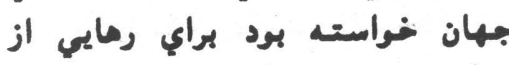

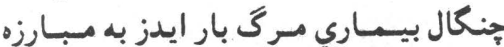
عليه اين بيماري آغاز كنند. بيسار

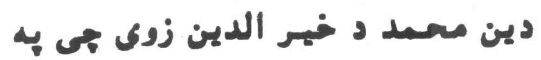
غلهكى سره يس د ناور ولسموالى او

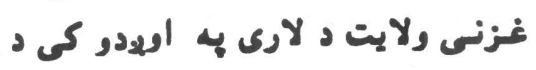

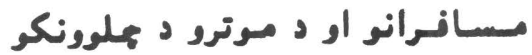

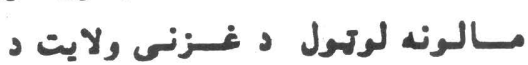

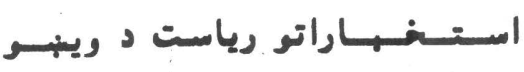

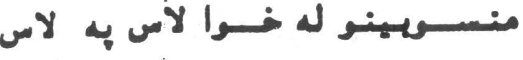

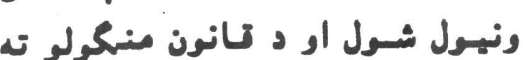
ومبارل شعرل.

\section{$.3 .45,16.53$}

صحبت ماي شان و عده سيردند كه

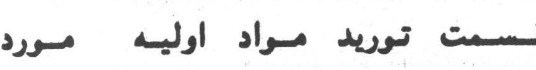

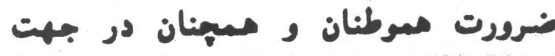

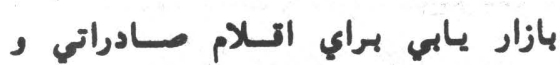

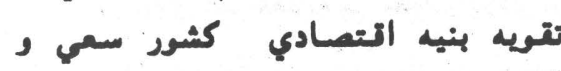
تلاش مس بانبه خواهند نمرد.

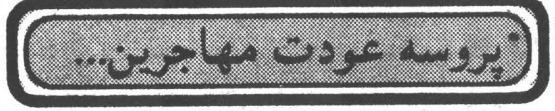

محمد صديق اخند زاده معين وزارت شهدا 